\begin{tabular}{|c|c|c|c|c|c|c|}
\hline \multirow{4}{*}{ Impact Factor: } & ISRA (India) & $=3.117$ & SIS (USA) & $=0.912$ & ICV (Poland) & $=6.630$ \\
\hline & ISI (Dubai, UAE & $=0.829$ & РИНЦ (Russia & $=0.156$ & PIF (India) & $=1.940$ \\
\hline & GIF (Australia) & $=0.564$ & ESJI (KZ) & $=8.716$ & IBI (India) & $=4.260$ \\
\hline & JIF & $=1.500$ & SJIF (Morocco & $=5.667$ & OAJI (USA) & $=0.350$ \\
\hline
\end{tabular}

SOI: $1.1 / \mathrm{TAS} \quad$ DOI: $10.15863 / \mathrm{TAS}$
International Scientific Journal
Theoretical \& Applied Science
$\begin{array}{ll}\text { p-ISSN: } 2308-4944 \text { (print) } & \text { e-ISSN: } 2409-0085 \text { (online) } \\ \text { Year: } 2019 \quad \text { Issue: } 06 \quad \text { Volume: } 74 \\ \text { Published: } 10.06 .2019 \quad \text { http://T-Science.org }\end{array}$

UDC 335. 47 519. 74.

SECTION: TECHNICAL SCIENCES

$$
\text { QR - Issue }
$$

QR - Article
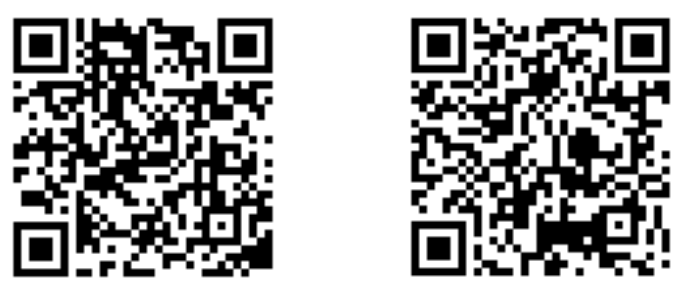

Artur Alexandrovich Blagorodov Institute of Entrepreneurship and Service sector (branch)

DSTU

bachelor, g. Shakhty blaghorodov@list.ru

Dmitri Olegovich Bordukh Institute of Entrepreneurship and Service sector (branch)

DSTU

bachelor, g. Shakhty bordukh95@bk.ru

Angelina Vladimirovna Kopylova Institute of Entrepreneurship and Service sector (branch)

DSTU

bachelor, g. Shakhty angelinakopylova22121999@mail.ru

Vladimir Timofeevich Prokhorov ISOP (f) DGTU

Doctor of technical sciences, professor of the department "Designing, technology and design", Shakhty prohorov@sssu.ru

Igor Mikhailovich Maltsev

Don state technical University associate Professor, candidate of technical Sciences, Department of Design and construction of light industry products, Rostov-on-don prohorov@sssu.ru

\title{
PECULIARITIES OF QUALITY MANAGEMENT OF DIGITAL PRODUCTION OF DEFECT-FREE AND IMPORT-SUBSTITUTING TRUE FOR CONSUMERS SFD AND SCF (1 MESSAGE)
}

Abstract: In report 1, the authors analyze the possibilities of policy and objectives of the company in the field of quality within the QMS in order to fight for defect-free production, reduction of marriage and guarantees consumers high quality of manufactured products. The use of Pareto charts allowed us to visualize the efficiency and effectiveness developed by the authors of the policies and objectives in the field of quality within the QMS to ensure defect-free production with a substantial decrease in the production of defective products. The need to improve the quality management system in the light industry is due to the following important reasons. First, it is increasing the confidence of potential consumers in the products that the company produces. Secondly, it is an opportunity to significantly strengthen its position in existing markets, as well as significantly expand its sphere of influence by entering new domestic and foreign markets. And thirdly - it is a significant increase in productivity of any industrial enterprise which is supposed to introduce QMS using participatory management. 


\begin{tabular}{|c|c|c|c|c|c|c|}
\hline \multirow{4}{*}{ Impact Factor: } & ISRA (India) & $=3.117$ & SIS (USA) & $=0.912$ & ICV (Poland) & $=6.630$ \\
\hline & ISI (Dubai, UAE & $=0.829$ & РИНЦ (Russia & $=0.156$ & PIF (India) & $=1.940$ \\
\hline & GIF (Australia) & $=0.564$ & ESJI (KZ) & $=8.716$ & IBI (India) & $=4.260$ \\
\hline & JIF & $=1.500$ & SJIF (Morocco & $=5.667$ & OAJI (USA) & $=0.350$ \\
\hline
\end{tabular}

Key words: QMS, certification, import substitution, demanded, conformity assessment, standardization, audit, demand, defective products, Pareto chart, quality policy and objectives, documentation, effectiveness, efficiency, responsibility.

Language: English

Citation: Blagorodov, A. A., Bordukh, D. O., Angelina, V. K., Prokhorov, V. T., \& Maltsev, I. M. (2019). Peculiarities of quality management of digital production of defect-free and import-substituting true for consumers SFD and SCF (1 message). ISJ Theoretical \& Applied Science, 06 (74), 37-67.

Soi: http://s-o-i.org/1.1/TAS-06-74-3 Doi: rossef https://dx.doi.org/10.15863/TAS.2019.06.74.3

\section{Introduction}

The effective demand of the overwhelming majority of Russian citizens do not allow them to focus on the quality of the goods. The shift towards interest in the quality of the goods must undergo mandatory step of expanding the range of goods available to the mass market, and this stage is not passed the Russians that in other matters does not mean deactualization quality goods.

$$
\mathbf{K}_{\mathrm{T}}=\underbrace{\sum \underbrace{e c+Д}}+\overbrace{\mathbf{C}_{\Pi}+\mathbf{P}}^{\text {subjective }}
$$

an objective component

where CT - quality of the goods;

$\Sigma$ es - the sum of the natural properties of the material; $D$ - activities become natural conditions in the goods; $J V$ - Buyer's consciousness;
Integrating the above, give the formula (1.1), which allows to reveal the terms of the quality of the product, ie the product produced by man to meet specific needs. Under it is possible to bring the phenomenon of natural origin and are included in market relations: clean air, mineral springs, mud, clay, warm sea, etc., and then, whose production is calculated not on the implementation, considering these cases as a simplified option:

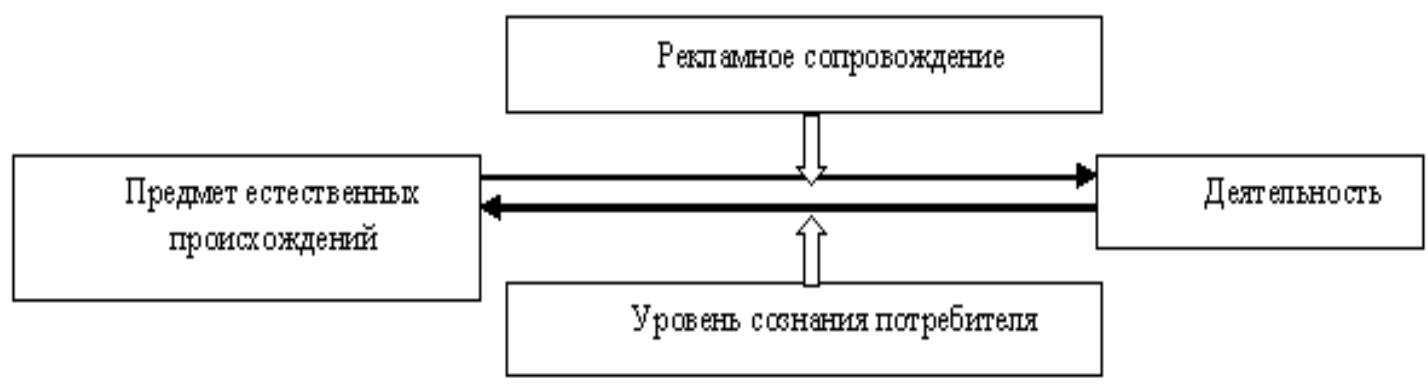

Fig. 1. Graphical equivalent of the above formula (1.1)

This formula describes the quality of intellectual products. For what it is necessary to expand the interpretation of the term "natural characteristics" to include in its intellectual content and psychophysiological preconditions of creative activity. Economic understanding of quality, on the foundation of which is directly developed all the known concept of quality management of production, has evolved according to the dialectical laws, despite the fact that economists themselves are not always aware of the dialectic process. [1-3]

The economic aspect
$R$ - advertising support.

Graphic equivalent of formula (1.1) is shown in the figure. one

The development of economic awareness of quality was carried out "under the influence of the contradictions between the internal and external objectives of the producer - ensuring product quality and thus strengthen the position of producers in the market (external target), as well as increasing the efficiency of production, that is, an increase in (internal target) company profits. At each stage of production, the market and society, this contradiction had its own peculiarities and different allowed. "

BS Aleshin et al identified four phases in the development of modern philosophical and economic 


\begin{tabular}{|c|c|c|c|c|c|c|}
\hline \multirow{4}{*}{ Impact Factor: } & ISRA (India) & $=3.117$ & SIS (USA) & $=0.912$ & ICV (Poland) & $=6.630$ \\
\hline & ISI (Dubai, UAE & $=0.829$ & РИНЦ (Russia & $=0.156$ & PIF (India) & $=1.940$ \\
\hline & GIF (Australia) & $=0.564$ & ESJI (KZ) & $=8.716$ & IBI (India) & $=4.260$ \\
\hline & JIF & $=1.500$ & SJIF (Morocco & $=5.667$ & OAJI (USA) & $=0.350$ \\
\hline
\end{tabular}

interpretation of the quality "phase of rejection", "quality management phase", "phase of continuous quality improvement" and "quality management program".

History of quality management economic its origin goes into the era of workshop production. In the medieval cities have to create a guild organization, one of the most important functions of which were masters certification. To become a recognized master was required to pass a serious test of its products on the quality. All products of craft artists have copyright "stigma" and was unique in its kind. Quality management is simplified by the production, manufactory his character, does not allow the production to turn on the scale. No harmonized quality standards at the time, of course, did not exist because of the difficulty to compare strictly tailor-made products of masters and even more to try to develop a kind of role model. The uniqueness of the wizard exclude imitation of anything at all.

Only much later, in the arms factories S. Colt appeared standardization of product quality. On such an unusual decision prompted by the fact that in the conditions of mass production of the final product is not going to become a specially made and tailored for his parts and of randomly selected from the respective party. Production for the first time equipped with special gauges and trained inspectors checked for their parts prior to assembly.

The flowering of the idea of standardization occurred in the era of development in the US car production. G. Leland, founder of the firm "Cadillac", came up with a couple of "pass" and "no-go" gauge. G.Ford by building an assembly line, went further. He replaced the input control components control the weekends, so on a major production - assembly, delivered calibrated, high-quality parts, which significantly increased productivity and significantly improved the quality of the final product. At the Ford plants as it was first set up Service technical control, independent from production.

F. Taylor, associate G. Ford, who worked in the creative tandem with his patron, has done serious work on scientific understanding of innovations in production. As a result, he was able to formulate the principles of scientific management, quality-oriented production: a systematic approach; personnel management; mandatory sharing of responsibility between the performers and organizers in achieving high-quality and efficient operation; the need for science-based regulation of labor.

FW Taylor, unquestionably the founder of scientific management. It was he who first discovered the "exhaustion" of the main provisions of the efficiency in management practices "initiative encouraging" for the quality of work. "In contrast, argued Taylor, the development of the scientific organization of production offers many rules, laws, formulas that take the place of private judgment of the individual worker and that can be usefully Applicability only after the systematic incorporation is made, measuring, etc.. their actions. "

One can not but agree with the summary of DM Gvishani: ... that in the strict sense of the term called Taylorism, is as follows [4-5]:

1. Creation of scientific foundation, replacing him old, traditional, virtually established methods of work, research of each of its elements.

2. The selection of workers on the basis of scientific criteria, their training and education.

3. Co-operation between management and workers in the practical implementation of the developed system of scientific organization of labor.

4. Even distribution of work and responsibility between management and workers.

Taylor himself was represented as a guarantee of quality of production and its effectiveness "Science instead of traditional skills; harmony instead of conflict; cooperation instead of individual work; maximum performance instead of limiting productivity; the development of each individual worker to the maximum available to him the maximum performance and well-being. "

Try to argue convincingly F. Taylor. Not surprisingly, his view of the organization and management of machine production hypnotized contemporaries.

There is an opinion, according to which the concept F. Taylor, G. Ford, A. Foyle and Weber "The main features existed to date and has become a model for the organization of production of most modern businesses. Only in the 70 years it began to come to replace another concept - the Toyota Production System. "

The ideology of "rejection phase" was simple and clear: the production output should be only highquality products, meeting customer and the defective product should not be allowed. The main efforts of control should focus on the quality control of components and assembly of finished products. The relative simplicity of "rejection phase" concept has been its reliability and relative to its reliability, reduced to the need for innovation in the future.

Reliance in the production of quality ideology on "phase of rejection" had a practical effect. It would be surprising if the result was not positive. Increased attention to the quality of the control logic is premised as a condition for the functioning of production. This requirement is at market level understanding accompanied by the development of industrial activity throughout its existence.

Surprising stability achieved pioneering development of scientific quality management 


\begin{tabular}{|c|c|c|c|c|c|c|}
\hline \multirow{4}{*}{ Impact Factor: } & ISRA (India) & $=3.117$ & SIS (USA) & $=0.912$ & ICV (Poland) & $=6.630$ \\
\hline & ISI (Dubai, UAE & $=0.829$ & РИНЦ (Russia & $=0.156$ & PIF (India) & $=1.940$ \\
\hline & GIF (Australia) & $=0.564$ & ESJI (KZ) & $=8.716$ & IBI (India) & $=4.260$ \\
\hline & JIF & $=1.500$ & SJIF (Morocco & $=5.667$ & OAJI (USA) & $=0.350$ \\
\hline
\end{tabular}

solutions of economic problems of production (and to some extent, and social) effects.

Yet hidden until the time of the party "rejection phase" was to appear. Bias control on the phase of preproduction quality - is essentially the same in the direction of the special status of the control functions, signaled an increase in the costs to provide quality products.

The quality of the production and quality of products are integrated, but not the same. Development of production undoubtedly due to the quality of manufactured goods. E. Deming fairly high on the list of the "seven deadly diseases" of modern production staged "production planning, is not focused on such goods and services, which shows the market demand."

Production of the transition from industrial to post-industrial society the mass consumer market is increasingly becoming a function of the "customer is always right" - as if it was not known the judgment is contrary to the seller forced to adapt to the demand of the buyer, he has no choice. No choice and the manufacturer, for which the "seller" - a "buyer".

product quality - a special "song" production. Only "concert" can not consist of a single song. Production quality is also characterized by its costeffectiveness. The pursuit of quality of products can not be an end in itself produce, otherwise a good cause becomes a deadly disease. Product quality is not able to compensate for the inefficiency of production in general.

Improving the quality of the final product always takes the cost of its provision, that becomes a problem for developers strategy of efficient production. Aims to improve production efficiency and improve the quality of manufactured products are not combined in the "rejection phase" concept, so it was replaced in the 20 -ies of the last century came "quality control phase". Its developers have attempted to overcome the critical value of the cost of the product quality, to the obvious "rejection phase." To resolve the contradiction he was not under force. It managed to soften. Among the innovators of reconstruction "phase rejection" stood out "Western Electric" American company employee technical control department V. Shewhart, a method of constructing diagrams, more known as "card W. Shewhart control."

In a first approximation, an initiative of the American specialist looks quite radically. W. Shewhart abandons a key quality control scheme F. Taylor, G. Ford. The quality control center instead of pre-production stage, which must be culled lowquality products, is the production process itself.

Method B Shewhart system was aimed at improving the process that was intended to help increase the quality of finished products.
The concept of W. Shewhart initially felt a dialectical approach. His predecessors tried to "expand the production on the shelves" and download the "shelves" so as to obtain the desired result. As a result, they handled one of the flank "shelves" and there was a distortion of the whole structure. Preparation Phase control has become the most expensive, while the main stage - Technological got from him dependent and has been relegated to the periphery of the control process, unjustly suffered.

W. Shewhart called "things" by their names, and set stages according to rank, highlighting the process. He risked, simplifying the preparation stage of production, reduction in quality of components. In return, he expected to receive a prize in the main unit of production.

Putting a priority in improving technology, the manufacturer increases the production process, making it more effective, in principle, due to the organization and technical equipment. As for marriage, it is advisable to monitor the organization of relations in the production, based on scientific research and the timely introduction of new products technical process, complete with training measures as a performer ready.

The production process is the main target of quality control B. Shewhart concept. Out it represents the flow of individual articles measuring quality parameters.

Ford's goal is still "get into tolerance" W. Shewhart sent to "retire". The idea of Mr. Ford worked his aroused new thinking. She was replaced by W. Shewhart forming a tandem: achieving sustainability of the process and reducing the variation of stability. The presence of variations V. Shewhart considered a natural formation. He even gave the process a quality criterion - sustainability of the process should be considered in the statistical sense. Variations parameters products have nothing but the realization of stable random process, the distribution function which is kept constant for a certain time.

B. Schuhart believed that variations in manufacturing parameters are the consequence of two groups of reasons: specific and general. Special rooted in violation progress of the production process. They are identified by means of the control card and eliminated on the basis of the testimony of such a card.

Common causes laid down in the bowels of the process. There are many, but they are not significant individually. Danger lurks in the amount of action similar reasons. Common causes of variation of parameters of the product are the subject of care managers, often high level and qualifications. His studies and actions, they are able to limit the action of general causes. At the same time V. Shewhart made two very valuable lessons that should guide the operator. 


\begin{tabular}{|c|c|c|c|c|c|c|}
\hline \multirow{4}{*}{ Impact Factor: } & ISRA (India) & $=3.117$ & SIS (USA) & $=0.912$ & ICV (Poland) & $=6.630$ \\
\hline & ISI (Dubai, UAE & $=0.829$ & РИНЦ (Russia & $=0.156$ & PIF (India) & $=1.940$ \\
\hline & GIF (Australia) & $=0.564$ & ESJI (KZ) & $=8.716$ & IBI (India) & $=4.260$ \\
\hline & JIF & $=1.500$ & SJIF (Morocco & $=5.667$ & OAJI (USA) & $=0.350$ \\
\hline
\end{tabular}

First, the search for the perpetrators is necessary, however, found guilty, we are rarely able to influence the situation. We must look for the causes of noncompliance and to eliminate them, involving in the process all of its participants.

Second, the source of defects and inconsistencies are process variations. Reducing the variation in the quality management system W. Shewhart - overall target. By linking the number of variations to the organization of the production process, W. Shewhart clearly aware that in order to reduce variations requires a new configuration of relations of people employed in production. The essence of the new configuration must be reflected in the friendly cooperation. Most people are rallying in feature production team [9].

System V. Shewhart - a serious step forward in comparison to F. Taylor system. F. Taylor focused on the mechanism of action, and W. Shewhart - on the mechanism of interaction of people across the entire spectrum of their relations: technical, economic, psychological.

Absolutely right BS Aleshin et claiming: "No such thing as" tolerances "(one of the most important inventions F. Taylor) clearly remains in working practices. "Tolerance" - a form of the language requirements for the quality, the quality of planning results. I have another: the opposition of planning

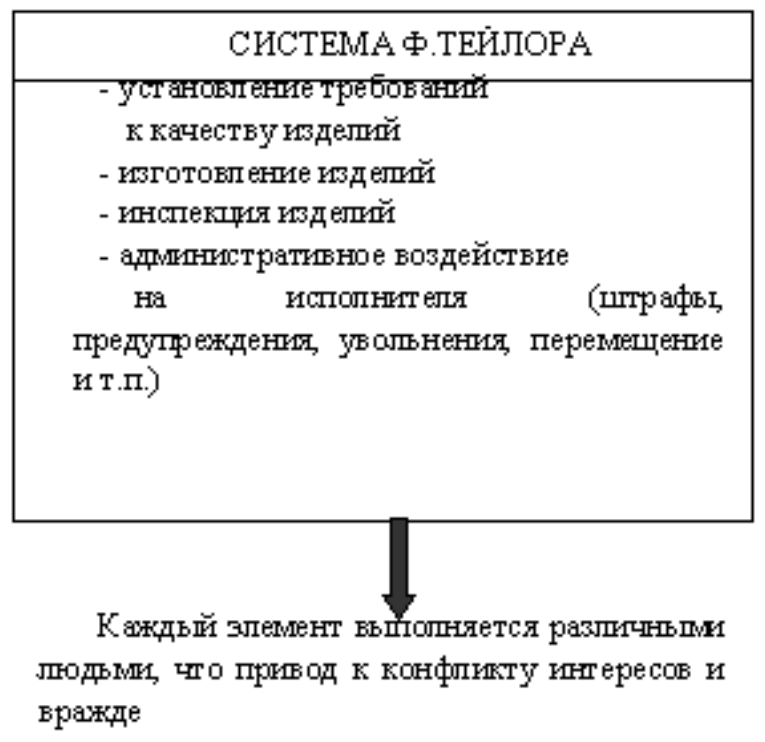

objectives, execution, monitoring and corrective actions. These tasks are performed by teams ..."

Comparison of two economic quality control systems mentioned above can be represented as follows (Fig. 2).

At the same time, we note that W. Shewhart's ideas and methods continue striving F. Taylor put the quality management on a scientific basis, it is used scientific methods in the organization of production. But here W. Shewhart "ahead of" F. Taylor.

Science (scientific methods) to F. Taylor, G. Ford came down to the fact of its ideas, which allow to quantify the mechanical action of a single artist, to find the best route and take it under effective control, pre-loading tasks to complete the program. "Classical" (Taylor) theory of the quality of its management had the support centrifugal force and motion and production: the division of labor and specialization of action, personality of the performer. This onesidedness of its critics realize.

W. Shewhart found it too simplistic mechanistic view of the development of production in general and quality management in particular. The production process is not only the resulting interaction between centrifugal and centripetal forces - individual and collective action: it does not allow the reduction of what is happening in it in terms of mechanical type.

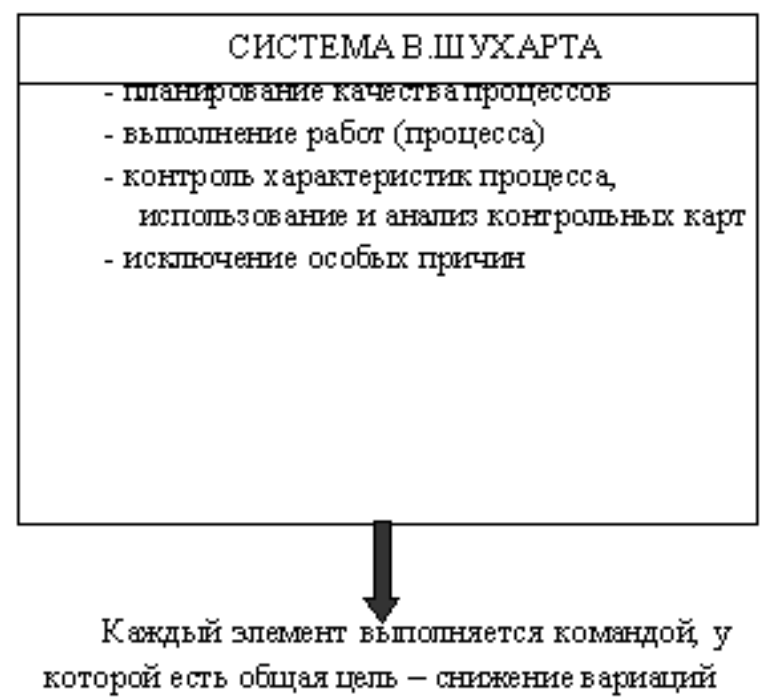

Fig. 2. Comparison of the Taylor system and Shewhart

The production involved a person as the subject of actions and attitudes. Moreover, the person as a subject of labor - the decisive factor of production. The development of production should be based on the development of the subject and the relationship between subject and subjects of relations.

Subjective potential in the form of individual knowledge, skills and aspirations - the main reserve of production efficiency that science helps to activate and organize properly. This understanding science includes social and human components.

The organic defect of the "classical" theory of quality management - to simplify the presentation and the nature of human behavior in organizations. W. Shewhart understood it and explained as best I could, 


\begin{tabular}{|c|c|c|c|c|c|c|}
\hline \multirow{4}{*}{ Impact Factor: } & ISRA (India) & $=\mathbf{3 . 1 1 7}$ & SIS (USA) & $=0.912$ & ICV (Poland) & $=6.630$ \\
\hline & ISI (Dubai, UAE & $=0.829$ & РИНЦ (Russia) & $=0.156$ & PIF (India) & $=1.940$ \\
\hline & GIF (Australia) & $=0.564$ & ESJI (KZ) & $=8.716$ & IBI (India) & $=4.260$ \\
\hline & JIF & $=1.500$ & SJIF (Morocco) & $=5.667$ & OAJI (USA) & $=0.350$ \\
\hline
\end{tabular}

and hoped to be clear and practical demand management.

New ideas of Shewhart not gone unnoticed in business, but apparently, the inertial force of business traffic is so great that the ideas are beginning to act on it only with time.

Short way to profit in the habit of thinking the easiest. Any complication associated with additional costs. Are they justified? In addition, to measure the mechanics of action is much easier than motivating activities.

It is not surprising that almost half a century by J. March and G. Simon noted:. Two views on the situation of people in the US are widely distributed in the organization, "the employee consideration as an inert instrument, it performs the specified destination, and treatment of personnel as something this rather than as a variable in the system. "With them in solidarity another reputable scientist M. Hare: "There are implicit assumptions about the person, which, it seems to me, based classical theory of organization and management: he is lazy, shortsighted, selfish, prone to errors, can not be judged sane and can even be a bit unfair. " In the text of M. Hare explains that the classical interpretation of the organization management is still very popular in practical management.

The three main provisions of the "classical" theory of quality management has not been eliminated so far. They continue to impress, warming the soul of ammunition, caressing them self, reinforcing selfconfidence in his election. Everything is so well laid out in its place: the employee - performer, in fact a "rational animal" with a clear dominant maximize economic findings; "Every individual responds to economic incentives as an isolated individual"; "People like the machines, can be treated in a standardized manner."
In W. Shewhart had many supporters who have left their own distinctive and valued trace: M. Follett, E. Mayo, C. Barnard, F. Roethlisberger, G. Simon. The thirties of the last century were marked by "humanistic challenge" "administrative responsibility of preaching."

In theory, events unfolded according to the logic script. The practice also was not as sensitive to changes in attitudes, so the efficiency of the new approach to economic management quality leaves room for reflection on the complexity of the relationship of theory and practice.

The construction of the economy hindered the implementation of the totality of progressive ideas. To a man turned into a production entity - mobilized their skills, knowledge, it is necessary that the economy has turned the "face" to the person who found the "human face". In another way, you can not enter the interior of the individual talents in production, to make them interested colleagues.

Dialectics warns: truth is concrete. The theory is effective in the specific historical framework. Her life can be long or short, but always finite. Elements of the theory and the experience of its operation, expressed in the lessons of history, continue to work, embodied in other current theories and practices.

Today's economic component quality can not ignore the purchase W. Shewhart, M. Follett, G. Simon and all those who have demonstrated the necessity of engaging in struggle for the quality of the subject's ability to think and get involved in the case. In particular, in our opinion, it is stored force "checklists" W. Shewhart. They are simple and allow the process of monitoring the quality of the performers and activities. And artists are clearer than not always understandable displeasure of control, so we give them the sample (Figure 3). 


\begin{tabular}{llllll} 
& ISRA (India) $=\mathbf{3 . 1 1 7}$ & SIS (USA) $=\mathbf{0 . 9 1 2}$ & ICV (Poland) & $=\mathbf{6 . 6 3 0}$ \\
Impact Factor: & ISI (Dubai, UAE) $=\mathbf{0 . 8 2 9}$ & PUHЦ (Russia) $=\mathbf{0 . 1 5 6}$ & PIF (India) & $=\mathbf{1 . 9 4 0}$ \\
& GIF (Australia) $=\mathbf{0 . 5 6 4}$ & ESJI (KZ) & $=\mathbf{8 . 7 1 6}$ & IBI (India) & $=\mathbf{4 . 2 6 0}$ \\
& JIF & $\mathbf{1 . 5 0 0}$ & SJIF (Morocco) $=\mathbf{5 . 6 6 7}$ & OAJI (USA) & $\mathbf{= 0 . 3 5 0}$ \\
\hline
\end{tabular}
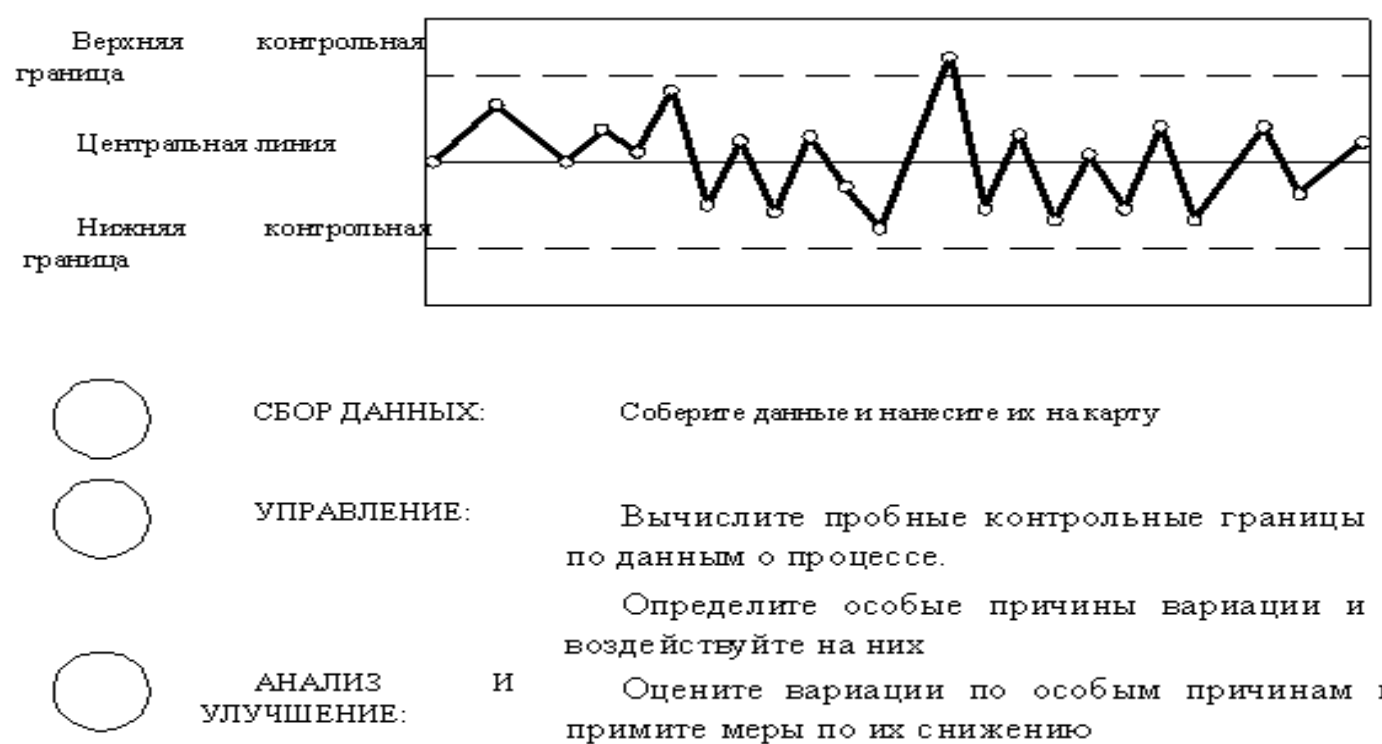

Coберите даннге и нане сите их на карту

Эти три фазы повт оряйте для непрерьпного упучшения процесса
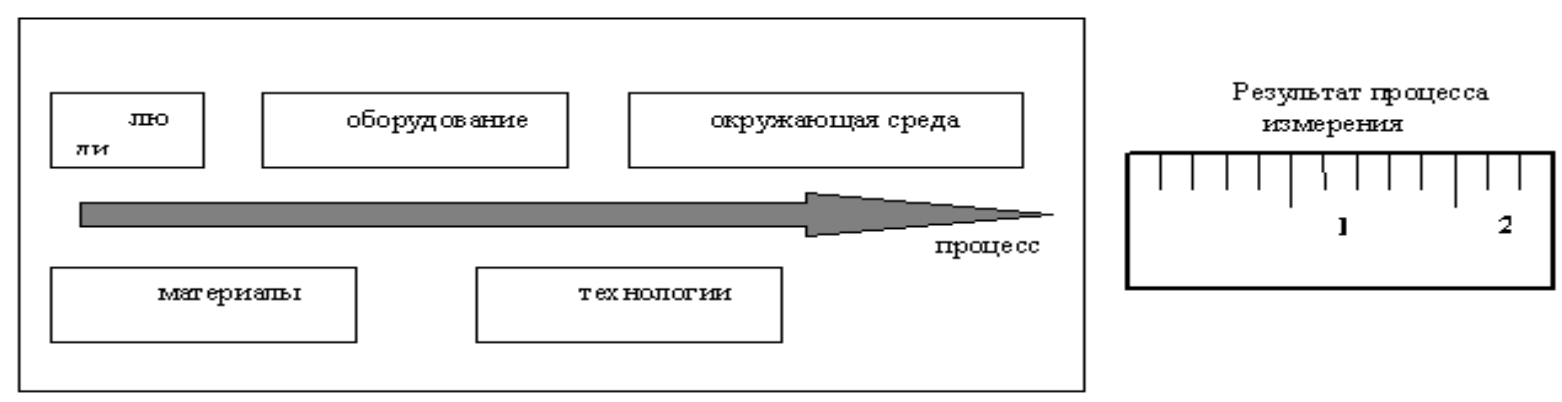

Fig. 3. W. Shewhart control chart

Developing a model for sustainable process, $\mathrm{W}$. Shewhart significantly expanded capabilities of scientific analysis of the quality of production, thus opened the aspects and stages of production, which remained in the shadows in the "classical" concept. He introduced the characteristic quality of the production concept of "adjustment process according to its dimensions," which is quite fashionable to be regarded as a specification with regard to quality management concept of "feedback".

In the theory of stochastic processes quantitative measure depending sequence of random variables is the autocorrelation coefficient that takes values from 0 to 1 . at values close to 0 for observation of neighboring (in practice <0.2-0.3), the process is considered to be "white noise". If the value of the autocorrelation coefficient close to 1 , then the process should use a different regulation system with feedback.

Not difficult to see in the Shewhart concept striving to theoretically comprehend the specific condition of mass production of his time. He tried to look on the conveyor through the eyes of science. And he managed to do a lot. At least, the ideas of Shewhart in our days, though aged, but still viable. When creativity they give a good result.

A remarkable contribution to the quality management practices was the creation of audit service quality, the function of which was significantly different from the challenges faced by the department of technical control F. Taylor. She was not concerned with grading and quality control to ensure system health by monitoring the workings of small batches of products. Thus W. Shewhart found a way of reducing the quality of expenditure, disproportionately increased with the organization of production on the recommendations of F. Taylor.

However, the original thinking W. Shewhart and his organizational skills were not allowed the old contradiction between the need to ensure the efficiency of production and the market demand for quality products, and the production itself in quality raw materials and components. Each production 


\begin{tabular}{|c|c|c|c|c|c|c|}
\hline \multirow{4}{*}{ Impact Factor: } & ISRA (India) & $=\mathbf{3 . 1 1 7}$ & SIS (USA) & $=0.912$ & ICV (Poland) & $=6.630$ \\
\hline & ISI (Dubai, UAE & $=0.829$ & РИНЦ (Russia) & $=0.156$ & PIF (India) & $=1.940$ \\
\hline & GIF (Australia) & $=0.564$ & ESJI (KZ) & $=8.716$ & IBI (India) & $=4.260$ \\
\hline & JIF & $=1.500$ & SJIF (Morocco) & $=5.667$ & OAJI (USA) & $=0.350$ \\
\hline
\end{tabular}

process has a limit yield of quality products. This limit is not incorporated in the process. He - system attribute is practiced in the company, causing the entire aggregate activities, especially the organization of labor and production management, including production quality. limit approximation leads to the rise of the main contradiction. Quality assurance requires more resources, which leads to a decrease in production efficiency.

In the fifties, a new concept of quality management. Her inspiration was E. Deming. The name of the next stage in the development of philosophical and economic understanding of quality management emphasizes its essence "phase of continuous quality improvement."

W. Edwards Deming proposed version of the software production quality was long-lived, existed "in authority" almost half a century, until the mid-nineties. This duration E. Deming practical relevance of the concept is explained, we think that it was skillfully "planted" on the foundation prepared by W. Shewhart, and representing a shape already software.

E. Deming management program is built on three axioms, focused on practical work:

first practical axiom states that any activity should be defined as the technological process, which implies the conclusion about the possibility of its improvement;

second practical axiom formed as W. Edwards Deming: the production has two forms of the state - is in a stable or unstable state. In both cases, not enough to solve particular problems, fundamental changes are needed;

third practical axiom E. Deming is as follows: High School of the enterprise management in all cases obliged to take responsibility for the result.

Practical, concrete axiom E. Deming's reach under a special program of management, summarizing the theoretical and real-world experience of quality management organization. The program presents several levels of interpretation and practical implementation of ideas: "Fourteen Points," "Seven deadly diseases", "Difficulties and false starts", "Chain Reaction Deming," "The principle of continuous improvement (Deming cycle)."

Of particular interest for the improvement of quality management practices in enterprises represent the penultimate and last sections of the program. "Deming Cycle" - is in fact a scheme proposed by W. Shewhart that recognize and Deming. "Chain Reaction" - a product of their own creativity E. Deming

In the cycle of Deming-Shewhart looped four stages: observation, the development of measures to improve the situation, implementation and analysis. task manager on the quality of the first of them gathering information and identifying weak links in production, requiring restructuring. In the second phase develops the head of organizational measures aimed at changing the situation. Among them, the connection of all the performers due to motivation. The next stage - implementation and monitoring of the process of modernization. Step completes the cycle analysis of the results from the introduction, capacity experiment to repeat the cycle.

Probably graphically Deming-Shewhart cycle best demonstrates the development of a spiral, each turn of the spiral - is a relatively closed loop action. It "rests", continuing the overall process, the next round. If it were not such a tradition to name the names of the authors of the discovery, the Deming-Shewhart cycle would be called "the spiral coil loop" quality management. Deming Cycle, Shewhart certainly relevant today for improving the organization of production, as it reflects the universal law of construction management. [6-7]

One can not but pay tribute to W. Edwards Deming and for the development of their "chain reaction" in quality management, shown in Figure 4. In it, he clasped his economic and social action, emphasizing the nature of historical time. 


\begin{tabular}{|c|c|c|c|c|c|c|}
\hline \multirow{4}{*}{ Impact Factor: } & ISRA (India) & $=3.117$ & SIS (USA) & $=0.912$ & ICV (Poland) & $=6.630$ \\
\hline & ISI (Dubai, UAE & $=0.829$ & РИНЦ (Russia & $=0.156$ & PIF (India) & $=1.940$ \\
\hline & GIF (Australia) & $=0.564$ & ESJI (KZ) & $=8.716$ & IBI (India) & $=4.260$ \\
\hline & JIF & $=1.500$ & SJIF (Morocco & $=5.667$ & OAJI (USA) & $=0.350$ \\
\hline
\end{tabular}

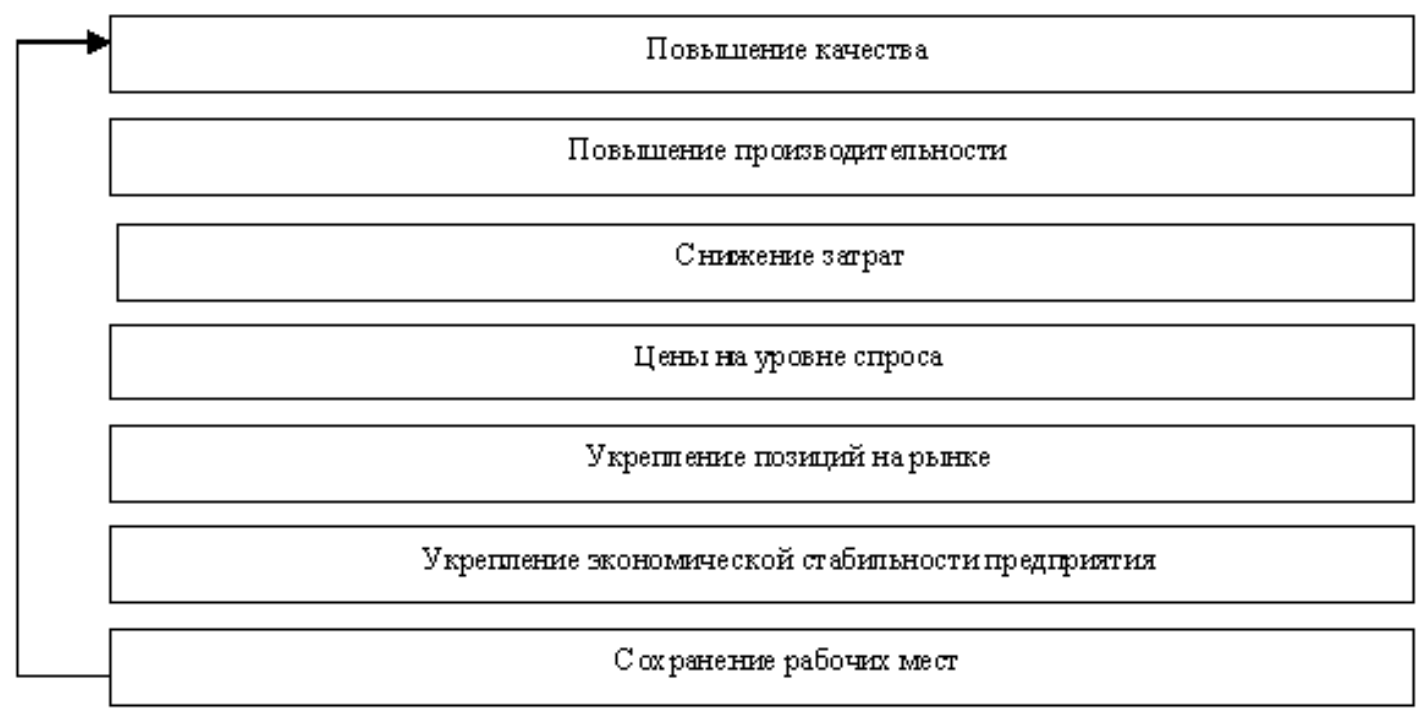

Figure 4. "Chain Reaction" on E.Demingu

Flowering of creativity E. Deming is connected with the revival of the Japanese economy. Government and industry argumentation Deming believed he deserved to share in the glory of the "Japanese miracle". His contribution in achieving the obvious and Japanese experts in the field of improving the quality of production, which are clearly marked in the study BS Aleshin et al:

"one. Perennial, consistent and purposeful solution to quality problems at the heart of everything good that accumulates theory and practice creates in this area.

2. consistency and persistence to establish a system of studying consumer demands - (prevention of major "Economics deadly disease," according to the classification of E. Deming - Ed.), Formation of respect for the customer and his requirements up to the cult of the consumer - (customer is always right - Ed.) user (in this case) is understood in a broad sense, as the next link in the process chain.

3. The quest for universal participation in the achievement of quality, from top executives to the performers of specific works.

4. Understanding that even well-established system of organization of work without regular inspections and improving the efficiency loses.

5. The organization works to ensure quality directly masters and foremen. Education, including special programs on national television, national conferences for masters and foremen.

6. Special attention - the mobilization of physical and intellectual potential of workers. quality circles group analysis of the situation at a specific site and to develop proposals to improve the quality and efficiency of the processes of production.

7. Extensive development of a permanent highquality value system of propaganda products to ensure high economic growth rates.

8. State influence on the radical improvement of the quality above all export products, including mandatory state certification. Trying to sell on the export of non-certified products is considered as contraband. State export support, assistance in the promotion of goods to the markets of other countries.

We deliberately did not cut the fragment describing the Japanese practice of establishing a quality management system because it is a mirror, the Russian failures are seen, it is the Russian, since announcing the Russian successor to the Soviet Union, Russian politicians and people close to them academic economists in 90 -e years systematically destroying the socialist experience in the construction of production quality, instead of rationally modified. Quality in 90 years none of those who should be responsible, there was no need for it. Economy refocused on raw materials, the quality of which is determined by either naturally occurring, or "compensated" realized quality.

A comparison of the economic policy of Japan 50s and subsequent years with the economic policy of the Russian Federation 90, announced the revival of Russia, leads to a sad conclusion: strong statements rarely correspond Affairs. Fatherland interests during Yeltsin's democratic reforms politicians worried the least, and the quality of all did not care, squandered the previous national acquisitions. However, the political 


\begin{tabular}{|c|c|c|c|c|c|c|}
\hline \multirow{4}{*}{ Impact Factor: } & ISRA (India) & $=3.117$ & SIS (USA) & $=0.912$ & ICV (Poland) & $=6.630$ \\
\hline & ISI (Dubai, UAE & $=0.829$ & РИНЦ (Russia & $=0.156$ & PIF (India) & $=1.940$ \\
\hline & GIF (Australia) & $=0.564$ & ESJI (KZ) & $=8.716$ & IBI (India) & $=4.260$ \\
\hline & JIF & $=1.500$ & SJIF (Morocco & $=5.667$ & OAJI (USA) & $=0.350$ \\
\hline
\end{tabular}

assessment of this phase of our history for a long time given, and we are interested in that part of the theory, which works directly on the economy. In this context it is appropriate to "walk" in a number of Japanese achievements, referring to the opportunity to learn from them the practical political-economic classes. Total conclusion is beyond doubt: the economy is not determined by the effectiveness of the quality of manufactured goods, and its range and quality. The transition from quantity to quality could be expected to only those who have simplified dialectics to stupidity. The new quality becomes not quantity quality and it alone.

Japanese teachers were Americans, but studied Japanese very seriously on the experiences - both positive and negative - the Soviet. We still have not decided on in practice. Our current declaration, certification whole world perceives skeptical. Who does not know how to appreciate and use their own achievements, not able to learn the true and others.

In Japan, the attitude towards quality has become a national idea, and embodied in the form of a "struggle" in which prestige was involved everything from janitor to CEO. Developed a system of mutual interests supported finance, organizational (quarries construction) and mentally. [8-9]

Main part

Modern economies are increasingly referred to as "smart," "zealous," innovation. This is a clear definition as compared to the "post-industrial", but as far as it adequately describes her condition - not an idle question. Character is manifested in the development, makes the planning of economic policy. The recent crisis clearly shows that, firstly, the planning is not merely compatible with a way of managing the market, - it is necessary to prevent and mitigate the negative phenomena are born undivided economic freedom, bordering on tyranny; Secondly, the ongoing crisis has revealed the limitations of the desire to imagine building the economy "smart". Smart economy should be, unfortunately only one mind, it is impossible to build.

The central figure of commodity production - not finance, as many policies, including domestic. Money - it is only the equivalent of goods and for all their stay. This product is created by labor, which, in turn, as a commodity. Therefore, the roots of the movement of the production goes to the corporate expression of human activity, primarily the work of consciousness, its potential.

The mind is not equivalent to consciousness. The mind - the tool of construction of consciousness. "Smart consciousness - knowing, artful, mobile - but no more. The mind needs as any force vector directing the application of mind, the construction of consciousness. The role played by the vector values: professional, national, universal. Consciousness melds them into a unique personal expression. "Smart" economy - no, if you do not put it on a foundation of values.

Important in personality - decisive factor of social reproduction - its morality. Not everyone can be a top - managers, general designers, VIPs in politics. Someone has to work brains, someone hands. The trouble comes when the "brains" and "hands" made sticky and adheres to them that are not supposed to. Immorality, undermining the foundations of professional culture and professional activities of the creative power is transformed into its opposite destroying created. Economy "smart" can be a terrible reality, if it will continue to be wicked. We are not utopians and idealists, are well aware of the concrete historical situation of morality. Now it is not about equality and fraternity - only on the conscience and responsibility. The economy can and should be, above all, responsible and "conscientious", then "smart".

While free competition is subject to the calculations - how to cheat a partner more effectively, consumers, competitors and the State ...; built on corruption and lobbirizatsii, handling work media sources for the natural development of the market. Cyclical economic crises will grow unnatural - system. System factor last - dishonesty and irresponsibility of the largest manufacturers.

And what it was to take the state, designed to be social guarantees for a democratic society and a defender of the rights of its citizens. It was forced to "pour oil on the fire" - to subsidize a bankrupt business scams to avoid economic and social collapse. However, European leaders are simultaneously sent to the "source of fire", "fire" - put further work at fault firms dependent on moral principles - introduced moral and financial regulations designed to sober up lost any measure of speculators. Symptomatic: it was France and Germany - the initiators of the rigid moral and financial monitoring - the first to feel the signs of economic recovery. England and the United States, affected in more corruption and less prone to moral dictates, continues to reap the benefits of freedom of conscience and social responsibility of the magnates.

Russia, as one would expect, has missed a real opportunity to use the crisis to revitalization of the national industry. First poured finances in banks, then very vague action taken with a view to wake up the conscience and responsibility of bankers. If he had forgotten that the banker without liquidity and liquidity, - "Two big differences." There was a chance due to national funds to force the banks to be leveraged lift industrial, scientific, and technical creativity in the country.

Situation can be changed by combining the mind, - we do not borrow it, and conscience - that the deficit for the years of democratic reform grew surprisingly 


\begin{tabular}{|c|c|c|c|c|c|c|}
\hline \multirow{4}{*}{ Impact Factor: } & ISRA (India) & $=3.117$ & SIS (USA) & $=0.912$ & ICV (Poland) & $=6.630$ \\
\hline & ISI (Dubai, UAE & $=0.829$ & РИНЦ (Russia & $=0.156$ & PIF (India) & $=1.940$ \\
\hline & GIF (Australia) & $=0.564$ & ESJI (KZ) & $=8.716$ & IBI (India) & $=4.260$ \\
\hline & JIF & $=1.500$ & SJIF (Morocco & $=5.667$ & OAJI (USA) & $=0.350$ \\
\hline
\end{tabular}

quickly. The reason for this should be sought in the alignment of economic mayhem and disproportionate increase in the administrative apparatus. Strange it turns out: The more officials, the less effective control, - the speaker is clear, and the same course. Our backlog of someone - a natural thing. In the historical "back of the field" subjects have their place, change places - the way it should be. For national development to keep up with the tragedy of time, losing in the "back of the field." The "eight" we were - the eighth, but in the "eight".

What we will be in 5-10 years, "twenty", time will tell. Economically, we are already there do not eighth, while retaining a place in the top ten. But still the memory of the majority of Russians time when the Soviet Union was behind the second line of the world economic rankings.

History does not come back, but that is no reason to forget history. How to continuation of the story was not, it is its continuation. Abandoning the national traditions, can be in "the broken trough". Falsifies not only the Second World War, distorted, ignored scientific, technical and industrial achievements of the country. Undermined faith in the national strength, the people's ability to regain lost ground.

The current situation - a daunting, yet it is not critical of those turning points of national history that seemed hopeless: after the devastation of the civil war, the loss of the most developed areas in the early years of the Great Patriotic War, exacerbating the enormous sacrifices of the working age population, experts. There was no finance available as seed money today. Therefore, the solution to the problem of creating a modern economy rests on technically need to develop effective management and control over the implementation of the adopted programs.

The program has come to change the plan. And what has replaced responsibility for the failure of the plan? The lack of an effective monitoring system - the most serious defect of the current economic policy, allowing amateurs to manage. The revival of the economy in the existing conditions of professional irresponsibility impossible. Only the professionalism and the associated responsibility for the business, which serves, can make the necessary transition to a new economic quality, economical to build and mobile economy on the basis of all-round development of science and promoting technical progress and improvement of vocational training.

Economy of the twenty-first century can be described in various ways. Not in the name of the essence of the definition - in the content of the concept. Divertifikatsiya names shows the diversity of the modern economy. Methodologically significantly distinguish the master unit or units in the set. Undoubtedly among the obvious contenders is the quality of the economy.
The presence of quality in the characterization of any phenomenon is invariant, as the quality combines the most significant signs of it. At the same time, it should be clearly understood that the very quality change - historically it concretely. Changes accordingly - should be changed - and the idea of the quality. From the first attempts A. Fayol, H. Ford and Frederick Taylor put the product quality control, serious crowned with success, in theory, it became clear: the future of the economy for quality work. Crucial for the economy is not so much the quality of the received for production of goods, but the quality of the organization and management of the quality of its production. For artisan and small-scale production and the quality of the sample of commercial products are combined with technology usually unchanged. Here, the quality depends entirely on the mastery of technique and technology in compliance with the stated conditions of the limited scale of production. Often the master, engineer, manager and marketer one and the same person.

Mr. Ford was first staged production of a complex product stream by separating operations and responsibilities, and thus determined the fate of a turn in quality. From now on, the quality of the fate determined by "infusing" factors - the organization of production, management and control. It came to the fore not the skill of the direct producer, and the ability to skillfully organize production, including its expanded reproduction, that is, supply, marketing, personnel management.

Divertifikatsiya activities revealed its special position in achieving quality results. The Second World War confirmed that staff and management decide everything!

Since the 1950s, dramatically intensified search for quality management programs through quality work. If at the beginning of the twentieth century, the relevance of acquired technical regulation of products and components, then half a century later there was a qualitative values clarification of technical regulations. At the epicenter of interests was already technical regulation of the organization and management of production, which is confirmed by the current international quality system regulation.

The displacement of the center of gravity in the understanding of economic policy aimed at ensuring the stability of production quality, in the direction of the technical regulation of the activity has not passed without the costs and dead-end route, which was expected in principle. Activities combined production is not homogeneous and is not autonomous, so the solution of problems "buried" in the methodological and theoretical "deficiencies" professional thinking.

The concept of "key activities" was justified for the first time A. Feigenbaum. In 1951 he published his book "Total Quality Control". ISO 9000 and ISO 


\begin{tabular}{|c|c|c|c|c|c|c|}
\hline \multirow{4}{*}{ Impact Factor: } & ISRA (India) & $=3.117$ & SIS (USA) & $=0.912$ & ICV (Poland) & $=6.630$ \\
\hline & ISI (Dubai, UAE & $=0.829$ & РИНЦ (Russia & $=0.156$ & PIF (India) & $=1.940$ \\
\hline & GIF (Australia) & $=0.564$ & ESJI (KZ) & $=8.716$ & IBI (India) & $=4.260$ \\
\hline & JIF & $=1.500$ & SJIF (Morocco & $=5.667$ & OAJI (USA) & $=0.350$ \\
\hline
\end{tabular}

14000 has been developed on the basis of proposals A. Feigenbaum. It was assumed that the two series of international standards will help to move from 'Business - conglomerates "to" enterprises - systems ".

In the process of industrial development under the influence of scientific and technological progress rapidly formed and sharpened the contradictions in the rate of change of the material side and the evolution of management thought, concerning the organization and harmonization of the production process. The latter is clearly not kept pace with the first hindering progress by increasing the risks and costs. The rigidity of central planning only worsened the situation, which explains the stagnation of the 1970s and the recession in the 1980s. Organizational chart, "the company - a conglomerate of" bad fit in the transition to a system of organization of the enterprise, primarily because not activate the initiative, creativity. It is no accident "Drummer", "innovators", "innovators" in the USSR, mainly engaged in the party, Komsomol, trade union organizations, standing essentially beyond direct production and form a superstructure over it.

Simplistically organizational diagram of such enterprises as follows (Figure 5).

The circuit construction of a control in which the main production units functionally autonomous and are connected indirectly through a common control, anti-system. When someone, something designs, others it should produce, and others - to control the quality, the fourth - to sell products on the market, divides participants in the proceedings to block the creative alliance. All partners are nominal process and have little idea who, what and why does. There is no team spirit, each acting on its own, at your own risk, often at the expense of colleagues, substituting the latter. [10-11]

The fundamental misconception "conglomerates enterprises' management is confident that their" brains "should be sufficient for the timely recognition and redress acts of God manufacturing process.

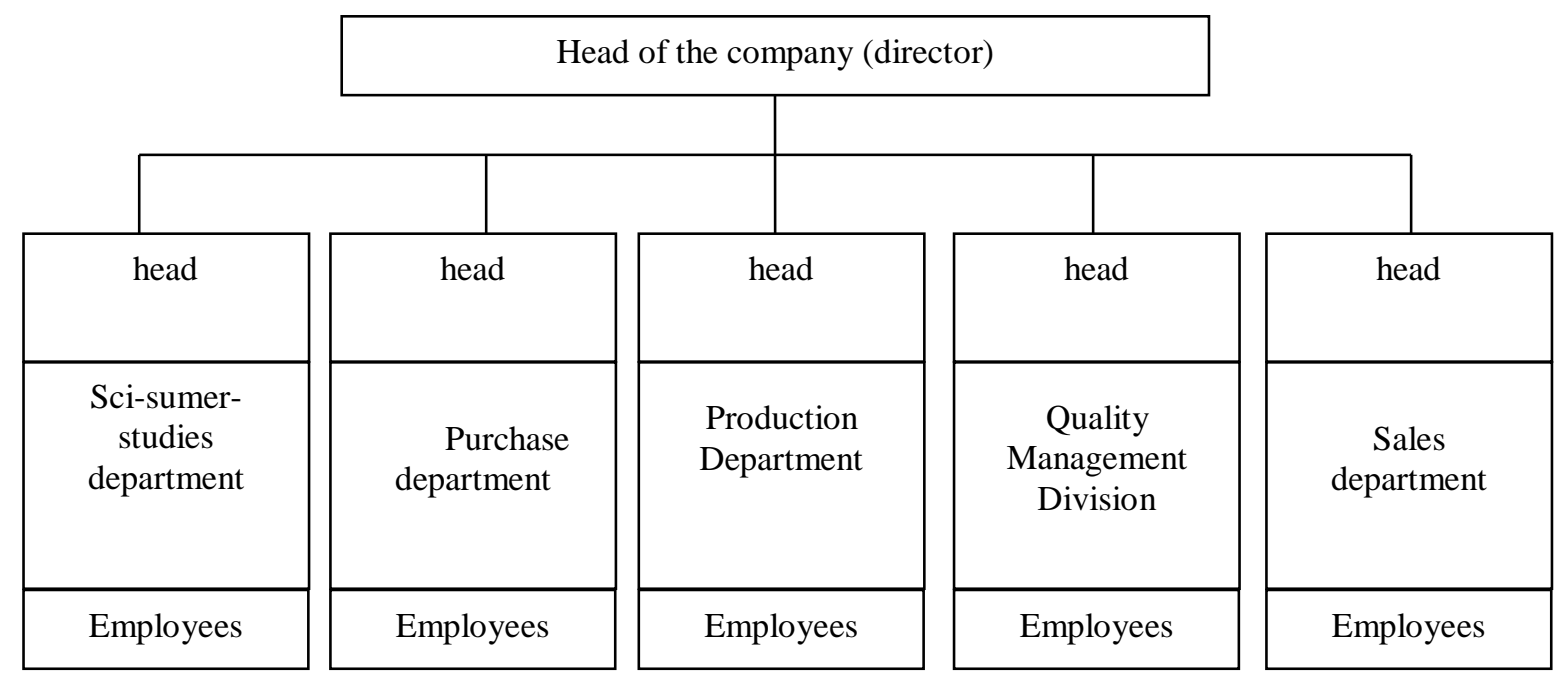

Figure 5. The organizational scheme

The control circuit "now-conglomerate" is essentially the same, despite the presence of a specialized department of the quality management scheme, since the functions of quality management department are reduced mainly to control activity.

In 1924, W. Shewhart proposed to optimize the control method using the principles of the theory of statistical variation, giving managers the statistical control chart. Improvement work is bound to affect the results, but it was limited to partial changes for the better. "The philosophy of the theory of variation" instead of using it as a base for the control was reduced to the level of statistical tools used by technicians with limited and very specialized areas of responsibility ... Ignorance of the theory of behavior of industrial processes made leadership is not able to recognize a situation correctly, require or do not require action. For this reason, management has become extremely vulnerable to the three types of costly mistakes of management:

1) the ratio of output to all variations of the process parameters as a surprise in the suppression of behavior and, in fact, the alleged reasons for them, which leads to the destabilization of the process;

2) the ratio of all the variations of the process output parameters as natural manifestations and omissions regarding detection and suppression of their underlying causes, which leads to an unstable behavior; 


\begin{tabular}{|c|c|c|c|c|c|c|}
\hline \multirow{4}{*}{ Impact Factor: } & ISRA (India) & $=3.117$ & SIS (USA) & $=0.912$ & ICV (Poland) & $=6.630$ \\
\hline & ISI (Dubai, UAI & $=0.829$ & РИНЦ (Russia) & $=0.156$ & PIF (India) & $=1.940$ \\
\hline & GIF (Australia) & $=0.564$ & ESJI (KZ) & $=8.716$ & IBI (India) & $=4.260$ \\
\hline & JIF & $=1.500$ & SJIF (Morocco) & $=5.667$ & OAJI (USA) & $=0.350$ \\
\hline
\end{tabular}

3) the assumption that the optimization and stabilization of the process - a technical solution, for which fully meets the specific department, not the solution of organizational problems, which requires the full support of management and the efforts of several departments. "

Restructuring of enterprise management system on the principles of the organization provides:

the relationship of key activities that the various departments of enterprises consistently involved in the coordination of actions, for example, on the revision of the quality of products to meet the specific comments of consumers, improving staff training, promotions, etc.;

integration of various processes in key activities;

the integration of new core activities in existing ones.

Dangerous error in the construction of control "now - the system" - consists in the interpretation of optimality as the sum of optimal reconstructions of individual units. In this case, the company is still regarded as a conglomerate, the amount of departments that play a special role. No opinion on the activities of both the integration of all its components.

The new term "quality revolution" is increasingly found in European literature. We will not speculate how adequately it captured the dynamics of policies aimed at improving the quality of production, we note only that the involvement in the study of the concept of "revolution" looks quite natural. Comparison of modern quality management practices in the not so distant past clearly indicates a radical restructuring of understanding of quality technology. In the "quality revolution" differentiate four stages:

1960 - a stage of self-determination of quality of the goods as the main factor of market competition;

1970 - a shift away from the dominant quality products to the quality of technology and production;

1980 - the transition from the quality and production technology for quality "Quality System" or "quality control system";

1990 - climbing to the quality of education, quality of intellectual resources.

Way of Europeans to the Bologna agreements was long and difficult. He drew many of the shortcomings and contradictions. In particular:

the apparent gap between the demands of the society industrialized nations to their existing education system and its capabilities;

discrepancy between what is most important discoveries and inventions are made preferably at the junction of Sciences, and the formation is based on the separation of objects;

lack of mobility retraining organization, its increasing backlog of accelerating changes in engineering, technology and science; momentum in the development of new educational paradigms, programs, methods, lag in the development of new textbooks.

Nevertheless, there is significant progress isolated and balanced three levels of quality education: university, national and European.

Intellectualization of the economy, increasing the conversion of science into a direct force of production, which are so fond of saying the specialists of the XXI century, exposed a fundamental contradiction between human consciousness and the mind decency. Philosophers have sought his permission to the wisdom of homo sapiens, stressing the basic function of morality. Hypertrophy activity of consciousness due to the actualization of intellectual abilities, focusing the creative forces of mind, bringing consciousness to thinking, advocates of "smart" economy does not see or do not want to see the crazy dependence on morality, the role of the mind in opposition to the value of moral values. We have already noted that the power of knowledge only in the particular scale can have its own vector. In systemic terms, the power of the indigenous knowledge is directed, rather than private and corporate interests of producers. Morality was formed as the first derivative of labor as a means of survival first, then the development of mankind. The main criterion of social progress can not be efficiency - this is purely an economic option. Man - a being public and the degree of achievement is determined by how the movement strengthens human relations - in the first place - the moral. Without the hard moral rules, which all the other aspects of human existence, there is no historical perspective.

The current crisis has revealed the vulnerability of democratic relations. Freedom of action, which led to the crisis, opened amorphous democratic postulates, not intelligent worship of regulating the market's ability without adequate perception of Action, "the powers that be." Innovations in economic construction express the new thinking of mankind is fused intelligence and morality.

The first to build an innovative economy Chinese and Indians, that is, those people who have kept in mind of the authority of moral values, subordinating scientific and technological achievements of national interests. It was they who in the near future "obuyut" and the Europeans and the Americans, and, apparently, we have too!

One hundred and fifty years ago, Marx wrote: "In our time as it is fraught with its opposite ... Even the pure light of science can not seem to shine differently, but on the dark background of ignorance. All our discoveries and all our progress as it leads to the fact that material forces are endowed with intellectual life, and human life, deprived of its intellectual side, is reduced to the extent of a simple material force. This 


\begin{tabular}{|c|c|c|c|c|c|c|}
\hline \multirow{4}{*}{ Impact Factor: } & ISRA (India) & $=3.117$ & SIS (USA) & $=0.912$ & ICV (Poland) & $=6.630$ \\
\hline & ISI (Dubai, UAE & $=0.829$ & РИНЦ (Russia & $=0.156$ & PIF (India) & $=1.940$ \\
\hline & GIF (Australia) & $=0.564$ & ESJI (KZ) & $=8.716$ & IBI (India) & $=4.260$ \\
\hline & JIF & $=1.500$ & SJIF (Morocco & $=5.667$ & OAJI (USA) & $=0.350$ \\
\hline
\end{tabular}

antagonism between modern industry and science on the one hand, modern poverty and decay, on the other hand, this antagonism between the productive forces and the social relations of our epoch is a tangible, unavoidable and indisputable fact. "

You can not share the communist conclusion of Marx, but one thing is certain - he is absolutely right in assessing the socio-economic situation of the midnineteenth century. Necessary restructuring has been and remains in the public consciousness. Money should not rise above morality, or collapse the main stronghold - homo sapiens - his wisdom. The legitimacy of the conclusions of Marx confirmed that socio-economic situation that has developed today in the shoe industry in Russia.

The liberalization of foreign economic relations played a role in her fatal accident occurred. On the one hand, an influx of better import footwear, leaving the Russian footwear is no longer in demand. On the other - using the law to put any price, our producers have raised them to the level of prices on imported shoes, and the level of quality remains the same. And for this reason it also stopped buying.

The government would have to intervene to protect their own producers (cheap credit, and customs barriers), but this was not done. The government did not help due to a mistaken belief: our light industry uncompetitive, so would be cheaper if the shoes start from abroad. In general, the government considered the light industry, as well as agriculture, "black hole", unworthy of investment.

When we hear about the protection of Russian producers of anything was, machinery and vehicles, clothing and footwear, food and furniture, etc., I always think about the shadow side of the coin of such innovations: the quality of goods. In footwear companies lose the incentive to improve and update the assortment of shoes, because in the absence of import people will take anything. But manufacturers have something else in mind: the decriminalization of revenues on the domestic market of clothes and shoes.

The need Russian light industry market totaling 1250 billion formed due to the following sources: 230 billion (18.4\%) - Russian legitimate manufacturers; 240 billion (19.2\%) - legal import; 780 billion rubles $(62.4 \%)$ - and vvezonny illegally manufactured counterfeit goods, the same pattern is typical of the footwear market.

Today the population of Russia takes on the order of 600 million pairs of shoes, the domestic industry produced only 52 million pairs (in 2077 - 46 million pairs), 100 million pairs - arrives at the official importer. Where does the rest come from more than four hundred million? Imported all kinds of illegal means, ie, It remains a huge amount of shoes that would be in demand if the domestic footwear enterprises provided financial support and legal protection.

Why no end of wanting to invest in the oil and gas industry? Why go to the car company's Russia? Why, even in agriculture is willing to invest? And why is the background of all these "why" investors do not go to the light industry?

The general answer is that there are no favorable conditions for investors. Because with the creation of joint ventures in the oil and gas and automotive industries all right, because there every now following ministers and governors. And even then the officials will be afraid to take bribes and will not chase investors bureaucratic circles. And the opening of the enterprises of light industry, because of their small volumes, entirely in the hands of bureaucrats. In addition, foreign firmachi argue: why in Russia to set up enterprises, take risks when there our goods and so good buy? And are the Russian and Western companies in China, where the ideal conditions for investment, where cheap, disciplined labor force, a stable where a favorable tax system ...

Today, the equipment at the enterprises of light industry are extremely worn. The coefficient updates in recent years, $0.4-0.6 \%$ per year. While foreign companies manufacturing equipment is replaced every 5-7 years, ie by $15-20 \%$ every year. How can you compete? [12-13]

For the modernization of the sector needs funds. They can either be earned by the enterprises themselves, or made available in the form of loans, or come from foreign investors. The possibility of the enterprises are very limited. Loans to commercial banks of the road, the government does not encourage preferential loans, foreign investors in the sector, as has been said, do not go.

Hence the answer to the question, what to do? Firstly, to provide enterprises loans at minimal interest, and even better - without them (as farms producing food, the national project "Development of agriculture"). Second, to create such conditions that in light industry, foreign companies have gone, in addition to bringing capital its design, production, management and so on. D.

It should be noted that the last twenty years have shown that light industry enterprises are very responsive to the slightest attention to him the authorities to change the situation. Get at least 1991, a well-known default. Imports rose, and immediately revived light industry. Three years was the growth. Another example. Exceptionally low export duties on raw hides led to their mass export abroad. Leather and shoe factories were left without raw materials. In 2000 he was introduced protective duties on the export of leather up to 500 euros per tonne (instead of 100 euros). As a result, the production of finished leather in Russia grew from 1.1 to 2.2 billion square meters. 


\begin{tabular}{|c|c|c|c|c|c|c|}
\hline \multirow{4}{*}{ Impact Factor: } & ISRA (India) & $=3.117$ & SIS (USA) & $=0.912$ & ICV (Poland) & $=6.630$ \\
\hline & ISI (Dubai, UAI & $=\mathbf{0 . 8 2 9}$ & РИНЦ (Russia & $=0.156$ & PIF (India) & $=1.940$ \\
\hline & GIF (Australia) & $=0.564$ & ESJI (KZ) & $=8.716$ & IBI (India) & $=4.260$ \\
\hline & JIF & $=1.500$ & SJIF (Morocco & $=5.667$ & OAJI (USA) & $=0.350$ \\
\hline
\end{tabular}

decimeters. Instead of importing leather goods started exporting them.

In favor of the revival of light industry is not only necessary, but also possible, speak today examples of the success of the individual companies in the industry in the Southern and North Caucasus Federal District, both old and newly created. We say that at least some.

Novorossiysk shoe factory "Breeze Bosphorus", the company created to "scratch", gives 16 million pairs of shoes a year, and all the shoes in demand..

"Gloria Jeans" Rostov company. It is also a new beginning with the cooperative. It provides products for 7 billion rubles (up to $10 \%$ of all Russian sewing goods and up to $30 \%$ - for children). Its products go abroad, including in the United States.

So is "Homeland" to lean on and earn its light industry, which has appeared in such a difficult situation, especially in the Southern and North Caucasus Federal District.

Not to mention that the revival of light industry would help to solve the social problems of the small cities of the Southern Federal District and North Caucasus Federal District, which are home today more than 16 million people. Here, with the beginning of the reform of the first die small factories (branch associations). But they seem small on a national scale, or industry. While the regional center for 10-20 thousand people any shoe factory with 300 employees - is a large, city-forming enterprise, which not only gave money to the budget and releases necessary for public goods, but also to ensure a decent life for many residents of the small town or district center.

It is unlikely that in these towns ever to be built car plants or branches of defense plants and legproming - please. But so far as we know, the problem in this formulation, the government is not even discussed.

I can not hear concerns about another problem, even threats, arising from the collapse of the light industry. Previously, every enterprise light 'industry, like any other, there were mobilization reserves (equipment, tools, materials, etc.), which allows for a day in the event of war go to release the necessary military products. Instead, dress shoes stitching tarpaulin boots, instead of suits and coats - tunic and greatcoat, instead of "fashionable sheepskin coats" -.. Soldiers coats, etc. God forbid that happens - we are not in that will feed and dress our army, especially since the SFD border district with a difficult situation. This is another reason why you need to take very seriously light industry.

Very urgent situation with the provision of children's shoes. Most Russian shoe enterprises continues to reduce the issue of children's shoes in the high rise in prices caused by the abolition of subsidies from the federal budget, and some shoe factories, including those in the Southern and North Caucasus Federal District, all stopped producing. In 2018 compared with 2009 production of children's shoes stopped.

In the consumer market SFD and North Caucasus Federal District of baby products of domestic manufacturers are actively pushed foreign suppliers, who can afford to pass on the implementation of the shoe with a condition of payment after the actual sale. However, that flooded our markets from overseas flow of beautiful and fashionable children's shoes, most of them not having the certificates of conformity, not to mention the hygiene certificates - is, from our point of view, a crime against children.

Consumer demand acting as the main factor influencing the formation of the range, which in turn is aimed at maximizing and meeting the demand of the population.

Consumer demand brings together a whole group of indicators, which will form a niche in the domestic footwear, namely:

age-appropriate and work:

children's footwear;

Shoes for the elderly;

leisure shoes;

Shoes for special purposes;

office shoes;

for socially vulnerable groups of people:

Shoes for the unemployed receiving social assistance;

Shoes for pensioners;

Shoes for individuals with chronic diseases;

given the characteristics of the regions:

footwear National;

exclusive shoes;

Shoes elite.

Thus, the implementation of the requirements of the basic parameters that shape consumer demand, will form the distinctive signs, which will have to meet a new range of footwear. include:

The parameters are determined by demand,

Comparative competitive advantages; product must have clearly defined features, or pronounced advantages in comparison with existing analogues of the market, products or services of competitors;

social orientation; it is necessary that the product fit into existing social conditions to the proposed product line with the established way of life and system of values of the consumer;

the ability to satisfy the customer; the product should perform all the functions to meet the key needs and requests of the buyer.

We propose the following set of measures:

creature regional development programs and the maintenance of domestic footwear production in the district; 


\begin{tabular}{|c|c|c|c|c|c|c|}
\hline \multirow{4}{*}{ Impact Factor: } & ISRA (India) & $=\mathbf{3 . 1 1 7}$ & SIS (USA) & $=0.912$ & ICV (Poland) & $=6.630$ \\
\hline & ISI (Dubai, UAE & $=0.829$ & РИНЦ (Russia) & $=0.156$ & PIF (India) & $=1.940$ \\
\hline & GIF (Australia) & $=0.564$ & ESJI (KZ) & $=8.716$ & IBI (India) & $=4.260$ \\
\hline & JIF & $=1.500$ & SJIF (Morocco) & $=5.667$ & OAJI (USA) & $=0.350$ \\
\hline
\end{tabular}

Adoption measures to reduce the imported footwear imported into the region. These measures should include primarily the suppression of trade shoes smuggled in without permission for its implementation in local markets;

help employment of young specialists, graduates in the existing and newly established footwear company;

help enterprises in the process of promoting domestic shoe brands in their local markets. First of all, it is necessary to develop competent marketing strategy for regional shoe companies;

creature special light industry enterprises lending program in the region, taking into account the specifics of the production: the seasonal nature of product and feature working capital turnover of the industry.

In our opinion, for the successful implementation of all these measures, the necessary interest of both federal and regional branches of power in the organization and development of the footwear cluster that will trigger lower prices for components materials on energy and transport, providing manufacturers due to price niche to offer domestic consumers demanded and competitive footwear. All combine to ensure the formation of such a long life and a strong position not only in domestic, but, most importantly, and in foreign markets. All you need is good will and commitment of all participants to implement the proposed activities. Such advances are made, now needed a strong will and desire of stakeholders. The range for the formation of a consumer niche is shown in Fig. 2 - 5

Again, the state of the quality of domestic products is the main basic foundation for the success of today's domestic enterprises. This conclusion has the right to life, because the quality - the oldest value of humanity. And it is on the quality of Russian goods, services, the quality of management, we are losing in the global competition. You anywhere in the world have seen complex products with the inscription made in Russia? We also have not seen ... 


\begin{tabular}{|c|c|c|c|c|c|c|}
\hline \multirow{4}{*}{ Impact Factor: } & ISRA (India) & $=3.117$ & SIS (USA) & $=0.912$ & ICV (Poland) & $=6.630$ \\
\hline & ISI (Dubai, UAI & $=0.829$ & РИНЦ (Russia & $=0.156$ & PIF (India) & $=1.940$ \\
\hline & GIF (Australia) & $=0.564$ & ESJI (KZ) & $=8.716$ & IBI (India) & $=4.260$ \\
\hline & JIF & $=1.500$ & SJIF (Morocco & $=5.667$ & OAJI (USA) & $=0.350$ \\
\hline
\end{tabular}
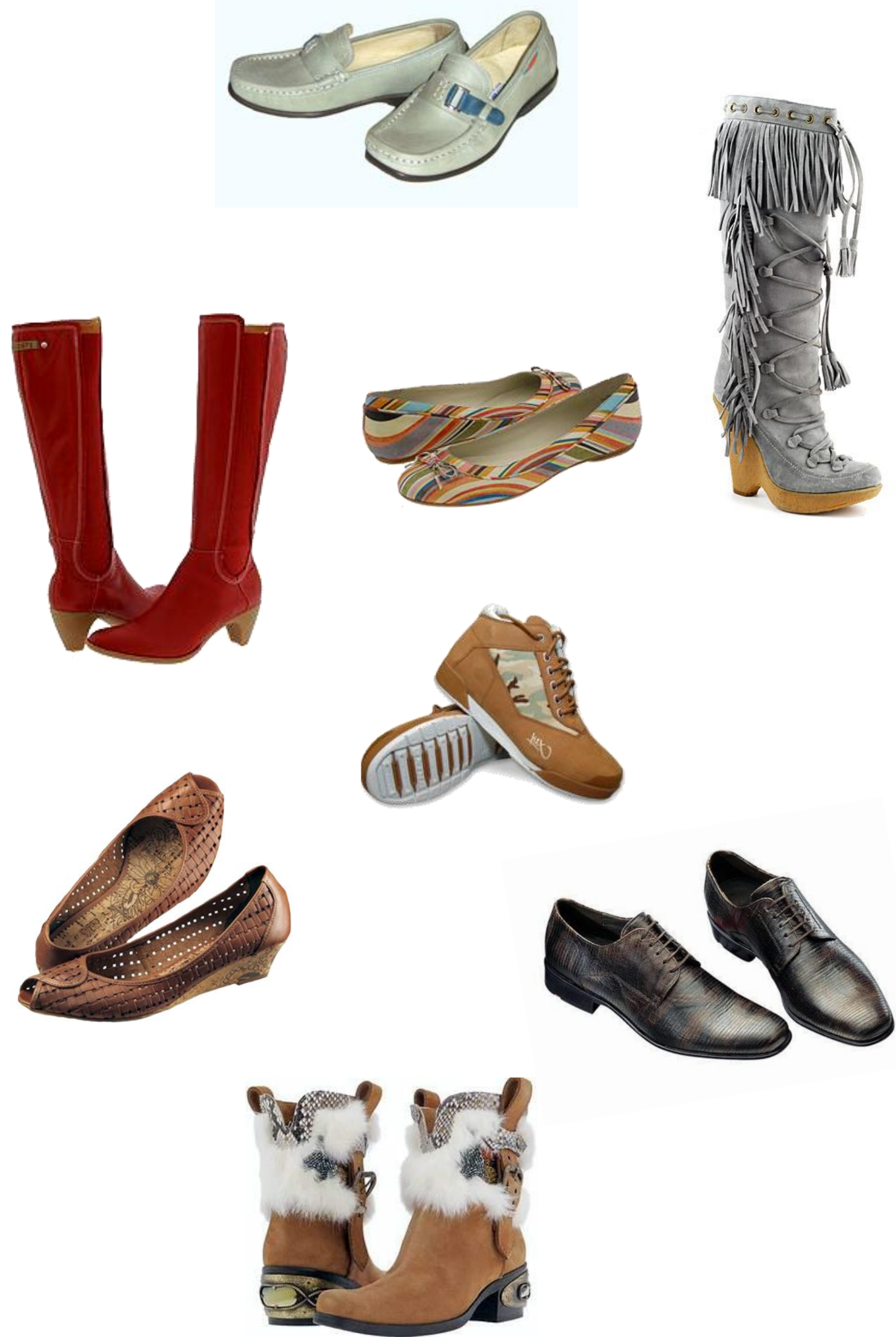

Fig. 6 The range for the formation of a consumer niche taking into account the peculiarities of the regions 


\begin{tabular}{|c|c|c|c|c|c|c|}
\hline \multirow{4}{*}{ Impact Factor: } & ISRA (India) & $=3.117$ & SIS (USA) & $=0.912$ & ICV (Poland) & $=6.630$ \\
\hline & ISI (Dubai, UAE & $=\mathbf{0 . 8 2 9}$ & РИНЦ (Russia) & $=0.156$ & PIF (India) & $=1.940$ \\
\hline & GIF (Australia) & $=0.564$ & ESJI (KZ) & $=8.716$ & IBI (India) & $=4.260$ \\
\hline & JIF & $=1.500$ & SJIF (Morocco) & $=5.667$ & OAJI (USA) & $=0.350$ \\
\hline
\end{tabular}

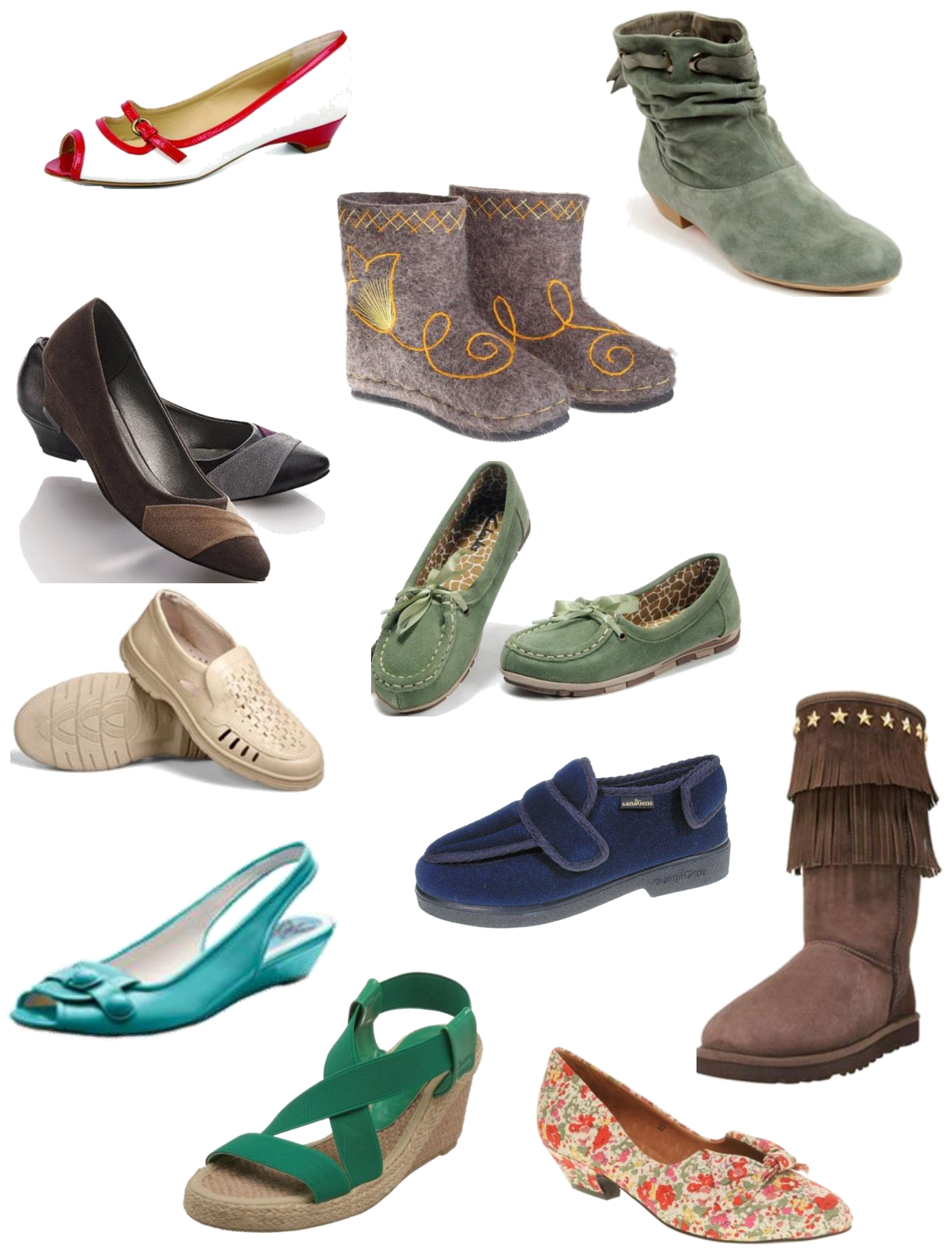

Fig. 7. The range of shoes for the elderly 


\begin{tabular}{|c|c|c|c|c|c|c|}
\hline \multirow{4}{*}{ Impact Factor: } & ISRA (India) & $=3.117$ & SIS (USA) & $=0.912$ & ICV (Poland) & $=6.630$ \\
\hline & ISI (Dubai, UAE & $=\mathbf{0 . 8 2 9}$ & РИНЦ (Russia) & $=0.156$ & PIF (India) & $=1.940$ \\
\hline & GIF (Australia) & $=0.564$ & ESJI (KZ) & $=8.716$ & IBI (India) & $=4.260$ \\
\hline & JIF & $=1.500$ & SJIF (Morocco) & $=5.667$ & OAJI (USA) & $=0.350$ \\
\hline
\end{tabular}

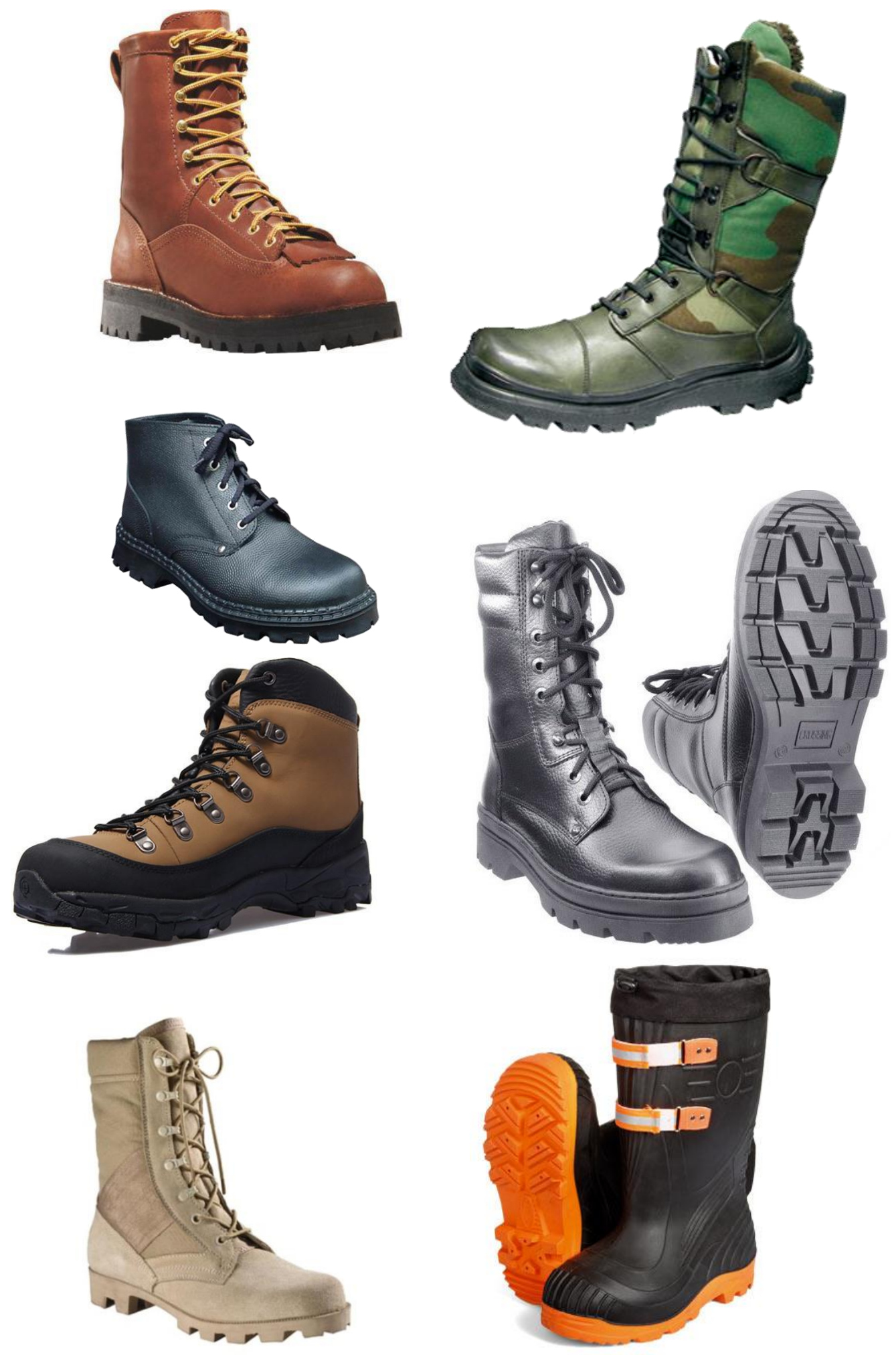

Figure 8. The range of men's work shoes and footwear for the military 


\begin{tabular}{|c|c|c|c|c|c|c|}
\hline \multirow{4}{*}{ Impact Factor: } & ISRA (India) & $=3.117$ & SIS (USA) & $=0.912$ & ICV (Poland) & $=6.630$ \\
\hline & ISI (Dubai, UAE & $=0.829$ & РИНЦ (Russia) & $=0.156$ & PIF (India) & $=1.940$ \\
\hline & GIF (Australia) & $=0.564$ & ESJI (KZ) & $=8.716$ & IBI (India) & $=4.260$ \\
\hline & JIF & $=1.500$ & SJIF (Morocco) & $=5.667$ & OAJI (USA) & $=0.350$ \\
\hline
\end{tabular}
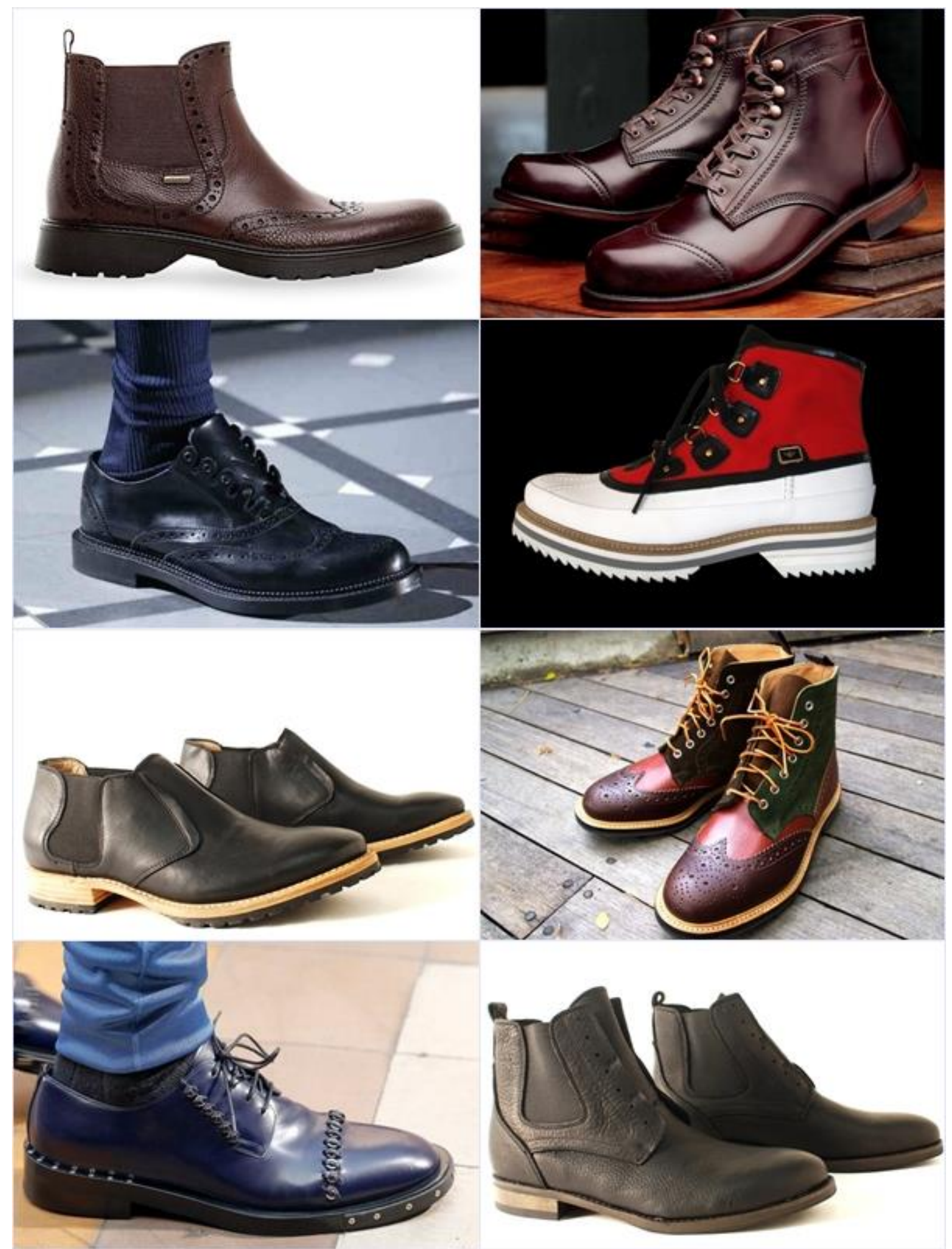

Fig. 9. elite assortment of men's shoes

Long hoped for a worldwide ISO system. Alas, in the Russian context, she slipped into a crisis. Excuse me, ladies and gentlemen of quality certification of the world, but it's time to list the public, what it has become and that recognize each other if not nearly all: [15-16] 


\begin{tabular}{|c|c|c|c|c|c|c|}
\hline \multirow{4}{*}{ Impact Factor: } & ISRA (India) & $=\mathbf{3 . 1 1 7}$ & SIS (USA) & $=0.912$ & ICV (Poland) & $=6.630$ \\
\hline & ISI (Dubai, UAE & $=0.829$ & РИНЦ (Russia & $=0.156$ & PIF (India) & $=1.940$ \\
\hline & GIF (Australia) & $=0.564$ & ESJI (KZ) & $=8.716$ & IBI (India) & $=4.260$ \\
\hline & JIF & $=1.500$ & SJIF (Morocco & $=5.667$ & OAJI (USA) & $=0.350$ \\
\hline
\end{tabular}

- an immense number of documents, navigate where no strength;

- meaninglessness of many of them (for example, under the terms of ISO required job descriptions, and all rush to go throw something and then forget them without a trace);

- One entrepreneur once said: "We have been certified by ISO ». And then he added: "I do not think we have certified such a Norwegian company." Can you guess what this is about? Yes, certificates of sale. Not all, of course, are sold, but the reputation is not accidental.

We agree on the terms. Quality - what is this? Compliance with standards, most will respond. Of course, where standards are possible, it is. Although standards have tolerances. And the difference between the upper and lower divisions is significant in these tolerances. And there standardization of the border. For example, contact with the customer. Everyone knows that the quality of the contact is critical to the success of the business when the prices, assortment, terms are aligned under the pressure of competition. It can be regarded as the standard specific set of welcoming words, the dress code, and so on. N. While we are well aware that they covered.

The current enthusiasm for describing business processes also gradually coming to an absurdity. And somewhere already reached him at various firms we have met strict description of the interview, not only for employment, but even the standard for meeting and negotiating.

Now, there is another approach: quality - is compliance with the client's needs, the user. Who buys, he is appreciated. It is only necessary to understand precisely what he values. If hit - that is, the required quality, that is, the degree of satisfaction of the consumer properties of the goods..[9].

But this approach is limited, and stretches from the last century. Then it was considered the undisputed formula: customer is always right. In our time, where the faithful friend imperative: the buyer does not know our capabilities.

What do we do? Understanding the quality of the correspondence (standard requirements) becomes obsolete. Today, much more capacious it becomes understanding it as compared to other products or to the same, but the same. Compare gives the product superior to the products, services of the service specialist on the expert, the organization of, the organization. A comparison of the standard or requirement does not imply superiority. There can only be equality. Standard and demand point to a minimum. And who is quite low? A little. But the superiority of interest to everyone, because the law is inexorable increase in demand.

Practically, this means switching quality evaluation system levels. For example:

A. Adequate quality, below which there is a defect, ie. E. Minimum permissible, the use of which will not cause damage.

B. The reference quality -.. On the basis of compliance with the standard, ie, the best available. The standard may appear from the standard, but they can be any pattern: from the fact that live have in the company, competitors, or at least somewhere as we know it.

B. Vanguard quality - what has been achieved for the first time, it exceeds the standards, but can count on effective demand and output profitability immediately or in the long term.

Here is a quality hierarchy may be allowed and a greater number of degrees. And again, it is time to abandon the idea that there is any quality can be measured. Rate everything is possible, but the measurement gives in a little of what is important to us.

Figure 6 presents a model of the complex process of product quality control and services produced in the individual regions, and in the shoe industry as a whole. [18-20]

The model is a closed loop (Control) control system implementing the principle of regulation "by the deviation". Quality of products in the consumer market can be characterized by a multidimensional indicator of quality $\mathrm{Q}$. In the course of conformity assessment, testing and certification of products is formed documented Quality Qd products. Q0 required high quality score is given to the best world standards in the technical documentation, technical regulations, national and international Standard ISO standards. V process of comparing these two values held by the competition commission is determined by the deviation of the actual quality score from the set:

$$
\Delta_{Q=\mathrm{Q} 0} \text { - Qd. }
$$




\begin{tabular}{llllll} 
& ISRA (India) $=\mathbf{3 . 1 1 7}$ & SIS (USA) & $=\mathbf{0 . 9 1 2}$ & ICV (Poland) & $\mathbf{= 6 . 6 3 0}$ \\
Impact Factor: & ISI (Dubai, UAE) $=\mathbf{0 . 8 2 9}$ & PUHЦ (Russia) $=\mathbf{0 . 1 5 6}$ & PIF (India) & $=\mathbf{1 . 9 4 0}$ \\
GIF (Australia) $=\mathbf{0 . 5 6 4}$ & ESJI (KZ) & $=\mathbf{8 . 7 1 6}$ & IBI (India) & $\mathbf{4 . 2 6 0}$ \\
& JIF & $\mathbf{1 . 5 0 0}$ & SJIF (Morocco) $=\mathbf{5 . 6 6 7}$ & OAJI (USA) & $\mathbf{0 . 3 5 0}$ \\
\hline
\end{tabular}

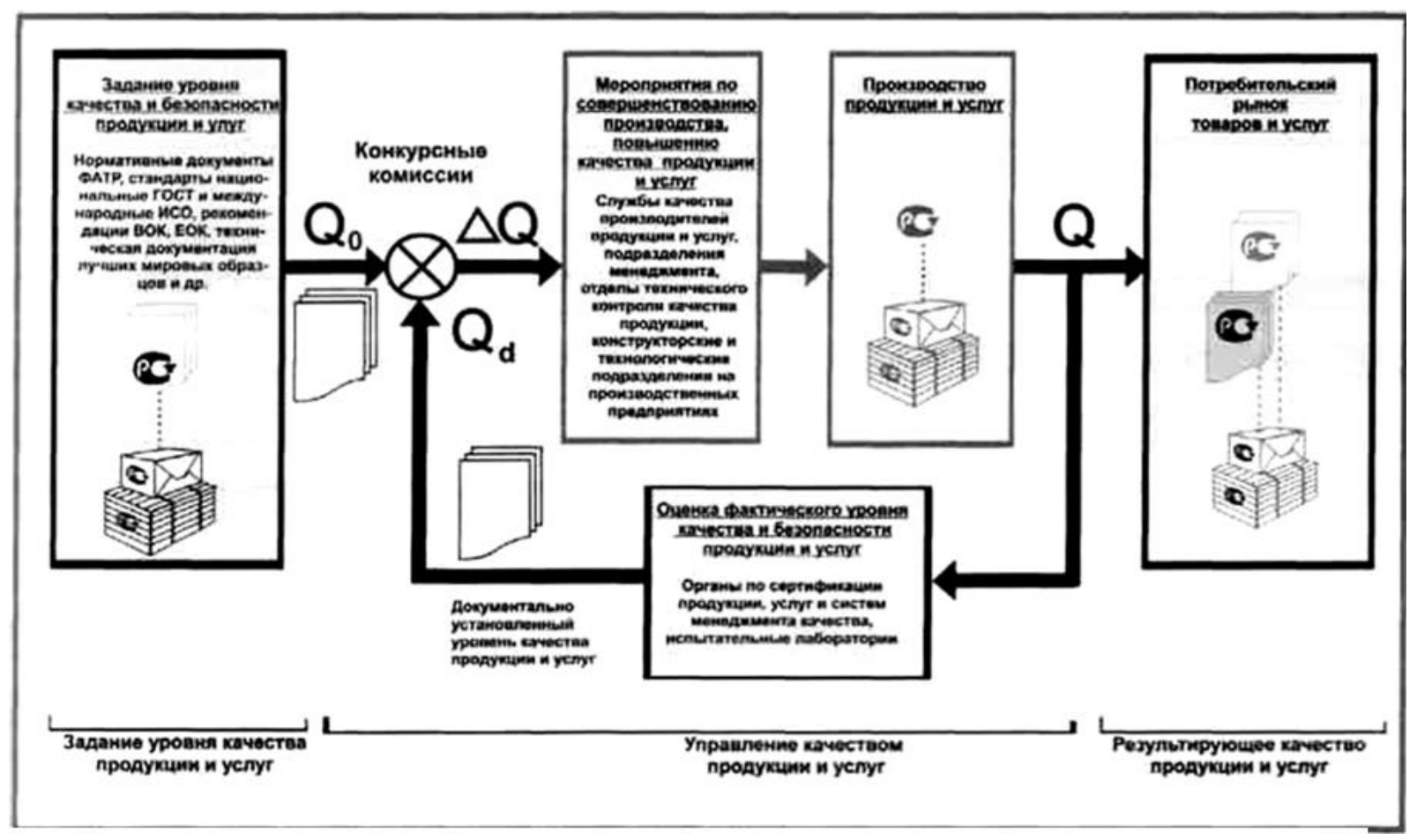

Figure 10- model of total quality management process of products and services in the region

This deviation $\Delta_{Q}$ (Mismatch in control systems) in this case is always non-negative ( $\Delta_{Q}$ $\geq 0$ ), As well-chosen given the high level of Q0 is always higher than the actual Qd or equal to what is almost rare. In this case, we have a system with a nonzero static error that is most characteristic of static systems with their inherent stability and speed, the accuracy of which is mainly determined by the gain of power and "proportional" control. In our case, the function control unit performs "Measures to ensure the specified level of quality products and services", modeling the enterprise quality management system, quality of service in manufacturing, whose actions take into account evaluation of the quality of products and recommendations of the competition committee. [6]

As can be seen from Fig. 3, quality Q produced and supplied to the market of products formed in the process of production as a result of measures to improve production, improve the quality of products and services carried out by the quality and units of quality management service, targeted actions are in turn determined by the results of product assessment in the implementation process .

In the new economic conditions is only a progressive production that is actively and dynamically respond to emerging challenges. The principle of "producing only what is needed, then when it is necessary, and as long as necessary", requires adapting the shoe enterprises to release products in small batches with frequent changes in assortment of shoes, that is, to the conditions of many small-scale production assortment. The effectiveness of the shoe factory, and in many respects, and the ability to survive in the competition, depend on the ability to quickly and cost-effectively be reconstructed to produce footwear respectively fluctuations in demand. A great opportunity for this opens up the development and introduction of flexible manufacturing systems.

Technological and organizational flexibility of production systems of variability determines the capacity of enterprises and their ability to react quickly and appropriately to changing market conditions and serves as a mechanism to optimize the structure of the technological system in order to reduce the cost of shoes. Thus, the development of flexible manufacturing processes of leather products ensures high performance with many assortment issue shoes and provoke a surge in demand for the products of shoe enterprises SFD and North Caucasus Federal District. Similar problems are common to other light industries. [21-22]

\section{Conclusion}

One of the problems in the system of improving the competitiveness of the region - to identify the region's potential clustering. Tradition of the footwear sector in the regions of the Southern Federal District, 


\begin{tabular}{llllll} 
& ISRA (India) $=\mathbf{3 . 1 1 7}$ & SIS (USA) $=\mathbf{0 . 9 1 2}$ & ICV (Poland) & $\mathbf{= 6 . 6 3 0}$ \\
Impact Factor: & ISI (Dubai, UAE) $=\mathbf{0 . 8 2 9}$ & PUHЦ (Russia) $=\mathbf{0 . 1 5 6}$ & PIF (India) & $=\mathbf{1 . 9 4 0}$ \\
& GIF (Australia) $=\mathbf{0 . 5 6 4}$ & ESJI (KZ) & $\mathbf{8 . 7 1 6}$ & IBI (India) & $=\mathbf{4 . 2 6 0}$ \\
& JIF & $\mathbf{1 . 5 0 0}$ & SJIF (Morocco) $=\mathbf{5 . 6 6 7}$ & OAJI (USA) & $\mathbf{0 . 3 5 0}$ \\
\hline
\end{tabular}

North Caucasus Federal District and the tendencies of its development are given the chance of success in the case of the interaction of all stakeholders - suppliers, manufacturers, government officials, trade and service companies. The first step towards such cooperation needs to be done in the course of an exchange of opinions and clarification of mutual positions. Definitely Do participants perceive the footwear market of the challenges that face them? What is the vector of structural changes in the Russian leather and footwear market - to the development or stagnation of the industry? What are the conditions and real opportunities for the development of competitive production in the region? What should be the support of the authorities at the federal and regional level? Is it possible in modern conditions to rely on cooperation and collaboration as a real competitive factor? How to solve the problem of training and retaining personnel in the production?

The theme of formation of regional clusters is highly relevant for the shoe business. Clustering - one of the most effective tools to improve the competitiveness of the territories. The necessity of the cluster approach to the management of competitiveness of enterprises, which is the development of new industrial policies to encourage the organization and development of clusters on the basis of forming relationships of network cooperation and public-private partnership (cluster policy) and includes the study of clusters, cluster strategies and techniques to ensure it is wand at Today. From the point of view of the cluster approach management process is viewed as a set of steps and measures for the organization of clusters and their development, ie, clustering. This approach will allow to compete successfully for small and medium enterprises of light industry, not only in the domestic but also the international market.

The role of regional and local authorities in the launch and coordination of cluster projects is very important, in this regard, we had established a mechanism for representing business interests in relations with the authorities. Proposed an element that performs the function of "coordinator and device". To develop this element need meaningful dialogue based on mutual trust and interest, primarily among themselves subjects of the industry - in the interest both the authorities and business. It is necessary to develop joint proposals for the directions, forms and methods of state support for the development of industrial clusters, namely:

Implementation new construction, expansion and reconstruction of production facilities, housing facilities, social and cultural facilities, public utilities and consumer services, administration, Ministry of emergency situations, environmental protection and ecological safety at regional level; [23-24] promotion to increase the competitiveness of production of industrial enterprises and its promotion on the domestic and foreign markets;

organization and implementation of software for production projects;

update logistics cluster production, introduction of new technologies;

preservation and the development of the accumulated potential in the sphere of science and scientific services; improving science funding mechanisms; implementation of research results in industrial and social sphere of the region;

achievement education quality corresponding state educational standards; implementation of the regional order to provide additional educational services; achieving a dynamic balance between the labor market and training of professionals; the development of higher and secondary vocational education.

The complex of anti-crisis measures for the easy management of industry, including the following priorities: industry;

increase the competitiveness of enterprises light

development industry information services; continued modernization of fixed assets;

easing lack of working capital;

increase efficiency of public administration; grouting non-payment.

Formed a plan of measures on realization of anticrisis program in the light industry, including:

regulatory and legal, scientific and methodological support of crisis management activities;

crisis support infrastructure light industry; expansion of business opportunities light industry;

financial support mechanisms and the development of anti-crisis activities light industry;

the development of interregional and international cooperation light industry in the crisis management field.

To further improve the regulatory framework of anti-crisis activity seems appropriate to the formation of the plan of measures on realization of anti-crisis program in the light industry, namely:

specification and detailing the objectives of sustainable development of enterprises of light industry should be built within the framework of the Development of the industrial sector of the economy, which is based on the structural transformation of the economy and the implementation of anti-crisis production technology development and export of consumer goods. As part of the development can be divided into three stages, the timing of which are presented quite conditional and can be adjusted in the 


\begin{tabular}{llllll} 
& ISRA (India) $=\mathbf{3 . 1 1 7}$ & SIS (USA) $=\mathbf{0 . 9 1 2}$ & ICV (Poland) & $\mathbf{= 6 . 6 3 0}$ \\
Impact Factor: & ISI (Dubai, UAE) $=\mathbf{0 . 8 2 9}$ & PUHЦ (Russia) $=\mathbf{0 . 1 5 6}$ & PIF (India) & $=\mathbf{1 . 9 4 0}$ \\
& GIF (Australia) $=\mathbf{0 . 5 6 4}$ & ESJI (KZ) & $\mathbf{8 . 7 1 6}$ & IBI (India) & $=\mathbf{4 . 2 6 0}$ \\
& JIF & $\mathbf{1 . 5 0 0}$ & SJIF (Morocco) $=\mathbf{5 . 6 6 7}$ & OAJI (USA) & $\mathbf{0 . 3 5 0}$ \\
\hline
\end{tabular}

course of implementation of the sustainable development of light industry enterprises:

2009-2012. - Anti-crisis development, providing for overcoming the crisis and restoring crisis losses of light industry enterprises and research resources for the subsequent transformation of the modernization of light industry

2013-2015 gg. - Investment renewal of fixed assets of enterprises of light industry, including quality competitiveness.

2016-2020 gg. - Innovative development beginning of mass development of new equipment and technology, the transition to the expansion into foreign markets of light industry products.

Using the developed and offered methodological provisions to improve the competitiveness of the region on the basis of the cluster theory will allow to make a decision about attraction and rational distribution of investment funds, aimed at implementing the necessary measures to improve the effectiveness of the cluster of subjects attractive and increase their competitiveness.

To solve this problem we offer a competitive range of men's, women's and children's shoes, taking into account factors affecting consumer demand: the main line fashion trends, taking into account economic, social and climatic characteristics of the regions of the Southern Federal District and the North Caucasian Federal District. As part of the strategy developed it will be organized production of competitive products using modern mechanized innovative technical processes. There will also be provided for the production of footwear to meet the demand for high-end consumer with a greater share of manual labor in order to give the shoe a target orientation and high demand.

To implement the developed assortment of men's, women's and children's footwear to offer innovative technological processes of its production with the use of modern technological equipment based on advanced nanotechnology, forming the basis for reducing the cost of shoes and, thus, increase its competitiveness in comparison with the same assortment of shoes leading firms with the possibility of release a wide range of shoe not only by type, but also on the method of attachment that will give it the relevance and increasing competitiveness. Introduced layout of process equipment, which represent an opportunity to shape the technological process for the production of men's, and children's shoes in the amounts that are determined by the existing production facilities in regions and used forms of organization of production, but of course, taking into account demand for its implementation in full amount of [25-26].

In this case, the financial health and stability of newly established enterprises in the regions of the
Southern Federal District and the North Caucasian Federal District is largely independent of the cash inflows, providing cover their commitments. The lack of minimally adequate supply of funds can cause financial difficulties for enterprises. In turn, the excess funds could be a sign that the company is losing money. The reason for these losses may be associated with both inflation and the depreciation of money and loss of the ability of their favorable location and generate additional income. In any case, it is a constant cash flow analysis will enable the company to control its real financial condition and prevent bankruptcy.

Cash flows from financing activities is largely formed in the development and financing of schemes in the process of calculating the efficiency of the investment project.

If the manufacturing of shoes will not fully realized, the company loses a part of the profit, which is necessary for the further development of production. To reduce losses manufacturer must have daily information on the sales of products and make effective decisions, namely: timely or change prices of manufactured assortment of shoes, or, which is more efficient and justified, to start production of a new, more popular in the market of footwear assortment.

Sales managers or marketers who control the process of selling specifically manufactured footwear range, every day should expect cash flow from its operating activities. As a result, monitoring of cash flow will have information about their net inflow from its operating activities. The decrease in sales volume will lead to a decrease in cash flow and will require a reduction in the selling price of the product in order to increase sales. If such an event does not lead to an increase in cash flow, it is necessary to take timely decision on whether to continue the release of this range of footwear.

For this calculation, important is the differentiation of data involved in the calculation. To calculate the cost of a particular output model input data are fixed and variable costs, which depend on the production equipment, the composition of the main and auxiliary materials, the number of employees and others.

The main source of data used in the monitoring process, is the selling price per unit of output and sales.

Thus, the calculation can be performed on a daily basis or in a selectable time range, in this case, asking only the sales volume and unit price of the product for a certain period, will receive the increment of cash flow for the period.

Calculations are made on the basis of assessment of performance and dynamics of production and sales, determining factors of influence on the change in the 


\begin{tabular}{llllll} 
& ISRA (India) $=\mathbf{3 . 1 1 7}$ & SIS (USA) $=\mathbf{0 . 9 1 2}$ & ICV (Poland) & $\mathbf{= 6 . 6 3 0}$ \\
Impact Factor: & ISI (Dubai, UAE) $=\mathbf{0 . 8 2 9}$ & PUHЦ (Russia) $=\mathbf{0 . 1 5 6}$ & PIF (India) & $=\mathbf{1 . 9 4 0}$ \\
& GIF (Australia) $=\mathbf{0 . 5 6 4}$ & ESJI (KZ) & $\mathbf{8 . 7 1 6}$ & IBI (India) & $=\mathbf{4 . 2 6 0}$ \\
& JIF & $\mathbf{1 . 5 0 0}$ & SJIF (Morocco) $=\mathbf{5 . 6 6 7}$ & OAJI (USA) & $\mathbf{0 . 3 5 0}$ \\
\hline
\end{tabular}

value of these indicators, identifying the internal resources and the development of mitigation measures, which should be directed to the acceleration of the turnover of production and reduction of losses, thus achieving significant economic effect.

Of great importance in the management of production output is assessment of actual production and sales within the production capacity, that is, within the boundaries of a "minimum - maximum" volume production. Comparison with minimal breakeven volume is used to determine, or "security" zone of organization and a negative value of "security" to phase out certain products, change the conditions of production and thus reduce costs, or to stop the production of these products.

Comparison of volume of output achieved with a maximum amount determined by the production potential of the organization, to evaluate the possibility of profit growth with an increase in output, if the increased demand or the proportion of the volume of sales of shoes on the market.

For shoe companies, striving for a strong position in the market, setting the price of shoes for the implementation is crucial to the success of the chosen strategy. Price is a tool to stimulate demand and at the same time is a major factor in the long-term profitability of its business.

In this connection it is necessary to conduct a break-even analysis.

Different ratios of sales volumes and prices of manufactured products. price reduction occurs when an enterprise in order to increase sales using a system of discounts. This event leads to an increase in revenue from the sale and obtaining additional profits. However, the area of revenue is not unlimited - when a certain volume of production continued its expansion becomes uneconomical.

The effectiveness of all these measures to create a cluster is possible only with the active collaboration of powers and the necessary support at the federal level - SFD and North Caucasus Federal District may fully or partially relieve the shoemakers of infrastructure costs while creating new industries within the cluster. And to solve the questions only federation may tax preferences; close the borders to imports of gray and black - again the competence of Moscow, given that the industry is in a serious depression that changes for the better need a very powerful set of tools and power solutions and joint action by all stakeholders.

Perhaps now, when Don shoemakers see how quickly their ranks are thinning under the pressure of competition, the willingness to work together will be higher. Otherwise Rostov very soon cease to be the shoe capital of the south of Russia.Finally, the institutional and organizational scenario suggests an answer to the question of how the cluster should be organized, how it should be formed and grown? For us, co-organization of cluster requires a minimum of four major technology groups that form the technological basis for the cluster: [27]

breakthrough scientific laboratory - pilot plants, which are based on new technologies;

development institution, based on which models and technology models will be created for for testing pilot plants;

industrial and technology groups that are capable of production tooling for the production of experimental series;

marketing groups capable of promoting a new type of product on the market and generate sustainable demand.

Administrative superstructure, providing the relationship of these four major technology groups with one another, may be:

investors Council Who decides on the priority funding of a project;

expert Council Considering various projects as they prepare for the implementation;

creative center, Prepare materials for decisionmaking advisory council and the board of investors.

Achieving the Millennium Development Goals can only clusters during the complex process of modernization of the real sector of the economy of the region. With regard to the Southern Federal District North Caucasus Federal District and it is only possible if the interests of all participating businesses. We are talking about areas such as:

increase the share of innovative sector and technological innovation in enterprises, forming clusters;

business development in the field of large, medium and small businesses and their collaboration to drive innovation, which leads to the expansion of existing and creation of new clusters;

strengthening linkages and interdependence of industry companies and research and educational centers and schools;

improving the territorial distribution of industrial enterprises.

In conclusion, considering the formation and implementation of cluster policy process in the region, we note that it is - a difficult task, the development and implementation of which shall be scientific in nature. Its success depends on a variety of factors and conditions, and the central place here belongs to the principles of scientific management and commitment to the dynamic development of the region, the interest of all branches of power, as the municipal and regional, and federal branches of government.

However, the weakest companies is the low level of information to ensure it is the technological preparation of production. This is explained byautomated CCI specialized and depend on the 


\begin{tabular}{llllll} 
& ISRA (India) $=\mathbf{3 . 1 1 7}$ & SIS (USA) $=\mathbf{0 . 9 1 2}$ & ICV (Poland) & $\mathbf{= 6 . 6 3 0}$ \\
Impact Factor: & ISI (Dubai, UAE) $=\mathbf{0 . 8 2 9}$ & PUHЦ (Russia) $=\mathbf{0 . 1 5 6}$ & PIF (India) & $=\mathbf{1 . 9 4 0}$ \\
& GIF (Australia) $=\mathbf{0 . 5 6 4}$ & ESJI (KZ) & $\mathbf{8 . 7 1 6}$ & IBI (India) & $=\mathbf{4 . 2 6 0}$ \\
& JIF & $\mathbf{1 . 5 0 0}$ & SJIF (Morocco) $=\mathbf{5 . 6 6 7}$ & OAJI (USA) & $\mathbf{0 . 3 5 0}$ \\
\hline
\end{tabular}

nature of production, type of product, the batch to release. In addition, the application software CAM is inhomogeneous for its intended purpose, it is formed from a set of products, each of which ensures the development of a separate kind of technological processes.

Therefore there is a need for an information support in the form of a universal database, in order to reduce labor intensity and improve work efficiency at the stage of technological preparation of production by their use.

To process the assembly shoe glue method of attachment created by the authors information provision, the purpose of which is to create a model of the passport and the automated selection process.

To create information support the authors performed the following tasks:

allocated criteria defining structure assembly process shoes adhesive fixing method based on a priori ranking and rank correlation techniques;

designed classifier and a block coding scheme shoe model for computer aided design process;

compiled Matrix matching processing steps depending on the design, materials and methods of processing workpieces upper, insole and sole of nodes, heels and spacers rationale for objective order schema compilation process and its choice algorithm;

designed structurally logical model shoe assembly adhesive fixing method based on the principles of the system approach providing optimum production technological solutions;

information support is designed for the automated design process shoe assembly as a set of databases that contain information about the different embodiments, the same processing steps depending on the equipment and the power company;

the algorithm of the program, under which formed precise instructions defining a computational process, leading by varying the initial data to the original result;

developed software that allows forming shoe assembly process glued attachment with simultaneous determination of the complexity and number of workers to produce a predetermined number of models.

The developed software fulfills the basic indicators of the quality of information systems, such as:

Flexibility - the ability to adapt and further develop, the possibility of adapting the information system to the new conditions, the new needs of the enterprise;

Reliability - the operation of information without distortion, loss of data on the "technical reasons" by creating backup copies of stored data, performing logging operations, to maintain the quality of communication channels and physical media, using modern software and hardware;

effectiveness - the ability to solve the tasks entrusted to it in the shortest possible time, optimizes the data and methods of their treatment, the use of proprietary designs, ideas, design methods, and confirmed its ability to minimally depend on hardware resources: CPU time, the space occupied by the internal and external memory, bandwidth used in communication devices;

safety - property of the system by virtue of which no unauthorized persons have access to information resources of the organization, provided setting start parameters so that the user running the application sees only the Main Switchboard form and a menu and a toolbar in which he can not use the buttons for the application developer.

Software in accordance with the algorithm processes the selected conditions and issues a print ready version of the process technology for this model of shoes from the calculation of the complexity and the number of workers, as well as the model passport. When using the developed information support task technologist for the formation process is to choose the model and structural features with the basic restrictions, which include the capacity, availability of equipment, production areas; analyzing the results; adjusting the selected condition (if necessary) and the selection of an optimal embodiment of the process.

As for the effectiveness of the implementation of information security, any enterprise can be evaluated from different perspectives, namely: economic, financial, organizational, temporal, environmental, social.

The result of any calculation method of separate application of evaluating the effectiveness of the proposed solution is able to reflect only a portion of their positive sides. Meanwhile, numerical values possible to use different criteria can vary significantly, and sometimes be in conflict. In such a situation the use of a synergistic justified (complex) evaluating the effectiveness of solutions that involve determination of advantages not one criterion, and on set of criteria.

The effectiveness of the introduction of the informational provision can be assessed in two ways: social and economic.

Social impact of the introduction of information support for automated design process is as follows:

1. The introduction into the educational process - improving the training of specialists through the use of innovative technologies in education.

2. As a result of the introduction into production - change in the nature and working conditions, equipment resource work, increasing professionalism, increase in the average duration of the free "paper work" time technologist. 


\begin{tabular}{llllll} 
& ISRA (India) $=\mathbf{3 . 1 1 7}$ & SIS (USA) & $=\mathbf{0 . 9 1 2}$ & ICV (Poland) & $=\mathbf{6 . 6 3 0}$ \\
Impact Factor: & ISI (Dubai, UAE) $=\mathbf{0 . 8 2 9}$ & PUHL (Russia) $=\mathbf{0 . 1 5 6}$ & PIF (India) & $=\mathbf{1 . 9 4 0}$ \\
& GIF (Australia) $=\mathbf{0 . 5 6 4}$ & ESJI (KZ) & $=\mathbf{8 . 7 1 6}$ & IBI (India) & $=\mathbf{4 . 2 6 0}$ \\
& JIF & $\mathbf{1 . 5 0 0}$ & SJIF (Morocco) $=\mathbf{5 . 6 6 7}$ & OAJI (USA) & $\mathbf{0 . 3 5 0}$ \\
\hline
\end{tabular}

Estimation of economic efficiency of introduction of information technologies often takes place either at the level of intuition, or not at all is produced. On the one hand, this is due to the reluctance of solution providers spend considerable efforts to carry out a detailed preliminary analysis, on the other hand, perhaps there is a significant proportion of consumers distrust to receive the results of such research. However, both of these problems stem from the same source - namely the lack of clear and reliable methods of assessing the costeffectiveness of IT projects.

Full economic efficiency of software for computer-aided design CCI consists of savings in the field of technological preparation of production, which is a consequence of the increased productivity of technologists working with automated selection of the list of technological operations with the calculation of the complexity and the number of workers.

In the production economy is obtained by selecting the optimal process result and unification typing received technological solutions. In addition, significantly reduced time pre-production, and this factor can not be overestimated in our time when competitiveness is only possible when frequently changing range of products, and for this it is necessary to achieve good technical and economic performance of the enterprise.

These and other advantages of automated selection processes, although many of them and it is difficult to determine by direct economic calculations, contribute a substantial improvement in performance footwear enterprises.

The results suggest the achievement of synergistic effect in terms of both techniques (due to the significant reduction of time for technological production preparation, selecting the optimum process, reducing changeovers process when changing the range, choose the correct starting sequence of samples), and from the point of view of efficiency production as a whole, due to the simultaneous achievement of social and economic benefits.

Today, from light industry, striving not only to survive but also to develop, it requires the ability to not only skillfully exploit the available technology, but above all, actively position itself in the market by delivering in the short term a high quality that meets the requirements, needs and expectations of consumers, products at the lowest price. In other words, at the moment it survives the one who will bring to market other products that best meets the requirements of consumers, while ensuring minimum cost of its production.

That should take the company to the listed indicators began its competitive advantages?
1. To understand not only current but also future customer preferences and to be able to develop products that correspond to these preferences.

2. Ensure setting manufacturing processes, guaranteeing them a minimum production cost due to the identification and elimination of all types of costs, the value of non-performing products.

3. Print the product to market faster than competitors do.

Implementation of these tasks will depend on how adjusted and will work for all enterprise divisions.

How can we ensure the streamlined and efficient operation? From our point of view,

by determining a set of processes or activities that ensure the production of quality products with characteristics that satisfy the requirements, needs and expectations of consumers SFD and North Caucasus Federal District regions;

establishing interprocess clear and intuitive interaction;

definition of quality objectives at the enterprise level and units that provide an understanding of the results to be achieved by departments, and that achieve the overall goals of the company;

resource planning needed to achieve objectives;

definition of procedures to ensure the execution of work in the departments most effective way;

measurement results and comparing them with the objectives;

analysis and decision making that should be improved within each division.

Thus, it presented a set of processes, due to the operation of which is formed by the enterprise management system, orienting it for production, corresponding to the requirements of its characteristics, needs and expectations of customers and set up all activities related to the provision of production to improve performance, such as:

built system for identifying the costs of sources, and the development of adequate measures to reduce them,

generated significant data demonstrating the efficiency of investments that can help attract new investors;

reduced production costs, which makes it possible to reduce the price, to expand the market and increase production;

a reduction in costs normally associated to the reduction in the number of marriages and other types of waste, which has a positive impact on such indicators of the enterprise, as the impact on the environment, the state of industrial safety;

generated image of a socially-oriented businesses; 


\begin{tabular}{llllll} 
& ISRA (India) $=\mathbf{3 . 1 1 7}$ & SIS (USA) $=\mathbf{0 . 9 1 2}$ & ICV (Poland) & $\mathbf{= 6 . 6 3 0}$ \\
Impact Factor: & ISI (Dubai, UAE) $=\mathbf{0 . 8 2 9}$ & PUHЦ (Russia) $=\mathbf{0 . 1 5 6}$ & PIF (India) & $=\mathbf{1 . 9 4 0}$ \\
& GIF (Australia) $=\mathbf{0 . 5 6 4}$ & ESJI (KZ) & $\mathbf{8 . 7 1 6}$ & IBI (India) & $=\mathbf{4 . 2 6 0}$ \\
& JIF & $\mathbf{1 . 5 0 0}$ & SJIF (Morocco) $=\mathbf{5 . 6 6 7}$ & OAJI (USA) & $\mathbf{0 . 3 5 0}$ \\
\hline
\end{tabular}

performed clear formulation purposes and tasks to each employee defining the result that should be obtained when performing work;

identify resources needed to carry out the work, and the provision of resources;

providing the knowledge and skills necessary for an understanding of how to do the work, to ensure its maximum effectiveness;

Measurement results of the work at the level of employees, departments and the organization as a whole and comparing the results with the objectives;

analysis of results and adequate response to them through a system of corrective and preventive actions.

As practice shows, the ability to implement these processes at senior management level creates the conditions necessary for the formation of a competitive enterprise, that is all a manager can already adopt to ensure their businesses this very economic stability.

In addition, it is important that different products were not too many. For the majority of Russian companies, the potential for optimization of the range is still laid in a significant reduction of the product range. Too large assortment of bad effect on economic performance - there are many positions that are on the volume of sales can not go even to break even. As a result, the overall profitability drops sharply. Only exception of unprofitable and low-profit products from a range of companies can give an increase in overall profitability by $30-50 \%$.

In addition, a wide range sprays enterprise strength makes it difficult to competent offer of goods to customers (even the sales staff are not always able to explain the difference between a particular position or name), dispels the attention of end users.

It is appropriate to recall the psychology of perception of the information. The reality is that the average person is able to simultaneously absorb no more than 5-7 (rarely up to 9) sense of constructive solutions. Thus, the person making the choice, first selects the best 5-7 options on the basis of the same number of criteria. If the seller offers a large number of selection criteria, the buyer begins to feel uncomfortable and self-eliminates insignificant, from his point of view, the criteria. The same thing happens when you select the actual product. Now imagine what happens when a man in front of a hundred almost indistinguishable (for him) of the goods, and he needs to buy one. People behave in such a situation as follows: or do refuse to buy, so as not being able to compare a number of options, or prefer what is already taken (or that sounds familiar). There is another category of people (about 7\%), lovers of novelties, which on the contrary will choose something that has tested them.

Thus, from the customer's perspective (for relaxing the selection of measurable perception embodiment) range should consist of no more than 57 groups, 5-7 of names, i.e., the entire range in terms of perception optimally should consist of 25-50 names. If the names of more than an objective, the output is only further classification.

It is generally accepted that a wide range of customer needs. This very wide range of often referred to even as a competitive advantage. But in fact it turns out that for a wide range of manufacturer - it's hundreds of types of products, and for the consumer 7 titles have more than enough. Thus, the consumer need not wide range and variety required for it.

It is possible, if they are implemented components of the strategy of development of Russia until 2025, namely, the problem will be solved by the transfer of economic development of Russia from the inertial energy scenario to alternative innovative socially - oriented type of development, the formation of an effective industrial policy, which requires:

- develop and legislate the basics of efficient state industrial policy as a system of agreed objectives, priorities and actions of state authorities, business and science to improve the efficiency of the industry, ensuring high competitiveness of products, goods and services and the steady growth of production. At its formation to provide outstripping growth in all sectors of high-tech products to increase its share in the total industrial production in 2025 at least $50 \%$, equality of subjects of industrial policy, security of property rights;

- ensure the implementation of special measures to support the priority high-tech industries, to create conditions for the effective development of the industry in Russia;

Ensure increased investment, creating economic and legal preconditions for the implementation and use of high-tech and new materials, primarily developed in Russia, it should be for this:

- legalize the basis of the national innovation system in the Russian Federation; Use higher rate on the R \& D expenses included in the cost; reduce the VAT to 12\%; exempt from taxation profits of enterprises invested in production; create long-term lending institutions modernization and technical reequipment industry by a low percentage; improve VAT administration system, change the order and terms of payment of taxes to replenish the industrial enterprises of working capital; the transition to the differentiated rates of tax on the extraction of minerals, depending on the environmental conditions, the degree of depletion of deposits, etc .;

- to develop and implement measures against price monopoly, to stabilize the tariffs of natural monopolies, to prepare and adopt a federal law "On the pricing and tariff policy"; contribute to the creation and promotion of domestic national, regional and corporate brands of domestic production for the 


\begin{tabular}{llllll} 
& ISRA (India) $=\mathbf{3 . 1 1 7}$ & SIS (USA) $=\mathbf{0 . 9 1 2}$ & ICV (Poland) & $\mathbf{= 6 . 6 3 0}$ \\
Impact Factor: & ISI (Dubai, UAE) $=\mathbf{0 . 8 2 9}$ & PUHЦ (Russia) $=\mathbf{0 . 1 5 6}$ & PIF (India) & $=\mathbf{1 . 9 4 0}$ \\
& GIF (Australia) $=\mathbf{0 . 5 6 4}$ & ESJI (KZ) & $\mathbf{8 . 7 1 6}$ & IBI (India) & $=\mathbf{4 . 2 6 0}$ \\
& JIF & $\mathbf{1 . 5 0 0}$ & SJIF (Morocco) $=\mathbf{5 . 6 6 7}$ & OAJI (USA) & $\mathbf{0 . 3 5 0}$ \\
\hline
\end{tabular}

development of a competitive environment in order to create competitive products, which implement a quality management system, promote the implementation of programs aimed at identifying, independent quality assessment and promotion of domestic products, to strengthen the standardization, including costs of research in this area for the development of new and adjustment of existing national std mouths;

- bear in mind that mechanical engineering is a system complex, which ensure a tight schedule its modernization and recovery of the technological basis of the national machine-building industry - machine tool. For these purposes, used as domestic development and purchase of foreign equipment and technology, using the international division of labor, wider use of the mechanism of the lease. In addition to general industry support measures must also prepare and adopt a national strategy for the development of machine tool industry for the period until 2020, including the implementation of special targeted programs aimed at funding promising scientific research;

- to modify the size and order of collection of customs duties to encourage imports of the latest technological equipment, while promoting the revival of domestic production of such equipment, in particular, to abolish customs duties and VAT on the import of new imported technological equipment, not manufactured in the country;

- to develop and adopt a set of special measures to ensure the mechanical engineering and machine tool industry, scientific and engineering personnel, highly skilled workers, especially in the field of scientific research and application development, generate employment system of young professionals; develop and adopt amendments to the Tax Code (. Chapter 25), establishes a regime of accelerated depreciation and preferences (premiums), allowing to absorb the active part of the fixed assets in excess of their carrying value;

- take measures to stimulate the system of public and commercial leasing process equipment for technical re-engineering industries; consider the possibility of pre-payment of 100 percent of the federal budget the cost of the supplies business is unique imported equipment, so those on a leasing basis, necessary for technical re-engineering and machine-tool construction purposes.;

- enter into the practice of carrying out a systematic census of the metalcutting equipment, which will have the objective data on the state machinery equipment machine-building enterprises;

- develop and implement a set of measures to address the problem of lack of qualified personnel in the industry, to improve the quality of training in higher educational institutions, to provide young professionals with housing on favorable terms, to put into practice training under the state order, based on public-private partnerships to provide modern facilities and dormitories vocational schools, to allow enterprises to the amount spent on training attributed to tightened Rata production in its entirety, to adopt special legislation and regulations aimed at ensuring industrial development of Siberia and the Far East;

\section{Conclusion}

- to develop and legislate a set of measures providing interest of economic entities in the active participation in projects of increasing resource and energy efficiency, including elements of the monetary policy, foreign exchange and investment regulation, subsidy mechanisms, special tax and depreciation regimes;

- implement a set of measures aimed at the massive development of small and medium enterprises in the industrial production, innovative sectors and in the service sector, primarily in the part of small and medium enterprises access to production facilities, procurement of equipment, ie including leasing. basis, the development of microfinance and credit cooperatives;

- to take steps to create a Russian processing industry a level playing field with the importers, to accelerate the development and adoption of the Federal Law "On Trade" and related regulations on the organization of effective functioning of the Russian wholesale and retail trade;

- develop a strategy for regional industrial development of the RF subjects, including the territorial distribution of the productive forces in the long term, the development of regional infrastructure linked with the placement of industrial facilities;

- be clearly defined system of implementation of the fundamental objectives of the state industrial policy, providing the solution of systemic problems of the real economy, to relate the need for investment, investment sources and achievable socio-economic results.

The Strategy of light industry development for the period up to 2020 and action plan for its implementation take into account the national interests of Russia (increase the level and quality of life, health of the nation, strategic and economic security of the state), the proposals of the Russian Federation, public organizations and associations on the necessary measures industry support in priority areas of development.

The strategy was laid on the transition of light industry on the innovative model of development. Particular attention is paid to the protection of the internal market issues from the shadow turnover, technical re-equipment and modernization of production, import and export. 


\begin{tabular}{llllll} 
& ISRA (India) $=\mathbf{3 . 1 1 7}$ & SIS (USA) $=\mathbf{0 . 9 1 2}$ & ICV (Poland) & $\mathbf{= 6 . 6 3 0}$ \\
Impact Factor: & ISI (Dubai, UAE) $=\mathbf{0 . 8 2 9}$ & PUHЦ (Russia) $=\mathbf{0 . 1 5 6}$ & PIF (India) & $=\mathbf{1 . 9 4 0}$ \\
& GIF (Australia) $=\mathbf{0 . 5 6 4}$ & ESJI (KZ) & $\mathbf{8 . 7 1 6}$ & IBI (India) & $=\mathbf{4 . 2 6 0}$ \\
& JIF & $\mathbf{1 . 5 0 0}$ & SJIF (Morocco) $=\mathbf{5 . 6 6 7}$ & OAJI (USA) & $\mathbf{0 . 3 5 0}$ \\
\hline
\end{tabular}

Today, light industry of the Russian Federation is the most important multi-disciplinary and innovative and attractive sector of the economy.

The contribution of light industry in Russia's industrial production today is about 1\% (in 1991 this figure was $11.9 \%$, and on a par with developed countries such as the US, Germany and Italy, which over the years keep the rate at $8-12 \%$ ) in exports $1.3 \%$.

Currently, in light industry operates 14 thousand. Large, medium and small enterprises located in 72 regions of the country. About $70 \%$ of enterprises are town-forming. The average number of industrial personnel employed in the sector, 462.8 thousand. People, $75 \%$ of whom are women. Scientific support is carried out 15 educational, scientific - research and design institutes, many developments which meets and exceeds the world level.

The main areas of facility location, determining the industrial and economic policies of the sector, are the Central (55 companies), Volga (30) and South (17) federal districts, which have the largest share in the total volume of production and the most socially significant.

The results of the industry for 2017 showed that it is in a crisis are able to increase the volume of production in the sub-sectors, focused directly on the market. It should be noted that during the crisis dramatically narrows the range of goods supplied to Russia. It gives domestic light industry strategic opportunities for employment vacated niches and strengthen its position in the market.

In 2018 the retail turnover of light industry products amounted to 2.0 triln. rub., the country's share of $14.5 \%$ in retail trade and in retail trade of nonfood products $26.3 \%$. According to the level of consumption of products of light industry is second only to food products, far ahead of consumer electronics, cars and other goods. Taking into account macroeconomic indicators and trends of the market of light industry products in 2025 could reach more than 3.3 triln. rub.

Existing preferences and solved in one degree or another problem on the federal and regional levels are still insufficient to eliminate the impact of negative factors on the development of the industry and turn it into a competitive and self-developing sector of the economy and domestic producers strengthen its position in the domestic market and compete on equal terms the world market not only with the Chinese manufacturers, Turkey, India and other developing countries, but also with the EU countries and the USA.

The situation in the industry has exacerbated the global financial crisis. In a crisis, even those enterprises which in recent years have achieved positive results in the innovative development, paying considerable attention to the modernization of production, has forced and will be forced in the next few years to reduce production and to abandon the long-term investments. This is due to difficulties encountered related to the involvement of bank loans (the proportion of borrowed funds in the working capital in recent years has reached $40 \%$ ), on the one hand, the increase in the volume of official imports, counterfeit and contraband products, the fall in demand and a slowdown in the implementation of many types of goods and consumer production technical purposes, reduction of workers and professionals - on the other hand.

The absence of radical measures to address these problems significantly affect the industry's economy, its technological backwardness in the near future may become an irreversible process that will lead to the degradation of science-intensive industries, to increased commodity dependence on foreign countries, the loss of state will geometrically increase, which will increase the strategic and national Russian danger.

Change the situation can only be developed and implemented anti-crisis measures and activities aimed at the economic recovery of light industry, giving it a new impetus to innovation, social and regional development, to improve the competitiveness and efficiency of the production of the new technical and technological level. Today the industry provides its products to only a quarter of demand of the population, and the mobilization needs of the country - only to $17-36 \%$, which is contrary to the law on national security, according to which the amount of strategic domestic production share should be at least $51 \%$. So today in front of light industry is facing new challenges and tasks that require new approaches not only in the short term but in the long term.

This resulted in the goal of the Strategy - to create conditions for accelerated innovative development of light industry Russia, to ensure effective compliance with the volume of production, the quality and range of products aggregate consumer demand, improve national importance the industry and its image in the world community.

The objectives and tasks of the Strategy comply with State policy in the sphere of Russian innovation and socio-economic development in the medium and long term. The strategy is intended to be: a major tool in solving problems of the industry and its interrelated tasks of economic growth with the needs of citizens, law enforcement agencies and related industries in high-quality and affordable consumer products, in the production of technical and strategic purposes.

Implementation of the Strategy will enable the Russian light industry to become an industrialized sector, which will provide jobs for thousands of people working to improve the well-being and 


\begin{tabular}{llllll} 
& ISRA (India) $=\mathbf{3 . 1 1 7}$ & SIS (USA) $=\mathbf{0 . 9 1 2}$ & ICV (Poland) & $\mathbf{= 6 . 6 3 0}$ \\
Impact Factor: & ISI (Dubai, UAE) $=\mathbf{0 . 8 2 9}$ & PUHЦ (Russia) $=\mathbf{0 . 1 5 6}$ & PIF (India) & $=\mathbf{1 . 9 4 0}$ \\
& GIF (Australia) $=\mathbf{0 . 5 6 4}$ & ESJI (KZ) & $\mathbf{8 . 7 1 6}$ & IBI (India) & $=\mathbf{4 . 2 6 0}$ \\
& JIF & $\mathbf{1 . 5 0 0}$ & SJIF (Morocco) $=\mathbf{5 . 6 6 7}$ & OAJI (USA) & $\mathbf{0 . 3 5 0}$ \\
\hline
\end{tabular}

strengthen the strategic and economic security of the country.

The main result of the Strategy - is the transition of light industry to a qualitatively new model of innovation, economic and social development, based on - a new technological and scientific base, new methods of production management, the relationship of science, industry and business. This is to ensure effective compliance with the volume of production, the quality and range of products the aggregate demand of the Russian and world markets.

Once again I would like to focus attention, that all of this will become a reality, if one important condition, namely, light industry products will be of high quality and with the interests of the consumer himself will be realized.

\section{References:}

1. Prokhorov, V. T., et al. (2017). The concept of import substitution of products of light industry: background, challenges, and innovations: monograph. Under the General editorship of Dr. sci. prof. V. T. Prokhorova (Eds.). Institute of service and entrepreneurship (branch) of the don state technical University. (p.334). Novocherkassk: Lik.

2. Prokhorov, V. T., et al. (2014). Revolution of quality: through the quality of advertising or real quality: the monograph under the General ed., prof. V. T. Prokhorov (Eds.). Isoip (branch) DSTU. (p.384). Novocherkassk: URGU (NPI).

3. Reva, D. V., Korablina, S. Y., Prokhorov, V. T., Narozhnaya, I. G., \& Tikhonova, N. V. (2016). Formation of import-substituting range of footwear for domestic markets // II international scientific and practical conference "Models of innovative development of textile and light industry on the basis of integration of University science and industry. Education-scienceproduction": collection of articles. 23-25 March 2016; M-in the image. and science of Russia, Kazan. NAT. research. technol. Univ. of Illinois (pp.364-371). Kazan: Publishing house of KAZAN state technical University.

4. Reva, D. V. (2015). Innovative technologies of production of footwear for consumers of regions of southern Federal district and skfo. K. G. Kovaleva, V. T. Prokhorov. New in equipment and technology in textile and light industry: materials of reports of the International scientific and technical conference. (pp.352-353). Vitebsk, Belarus: UO "VSTU".

5. Reva, D. V., Davtyan, G. G., Korablina, S. Y., Prokhorov, V. T., Osina, T. M., \& Tikhonova, N. I. (2016). Formation of conditions for import substitution of footwear in the regions of the southern Federal district and the southern
Federal district. Leather and fur in the XXI century: technology, quality, ecology, education: materials XII International scientific conference. (pp.320-327). Ulan-Ude: publishing house of ESSUTM.

6. Reva, D. V., Shrivel, I. S., Maltsev, I. M., Prokhorov, V. T., Osina, T. M., \& Volkov, G. Y. (2015). About the capabilities of the software product for assessing competence of experts in customs as experts of light industry products. news of higher educational institutions. North Caucasus region. Series: Technical Sciences, № 1 (182), pp.42-53.

7. (2018). Managing product quality through motivation behavior of the leader of the group of light industry enterprises: monograph / under the General editorship of Dr. sci. prof. V. T. Prokhorova (Eds.). Institute of service and entrepreneurship (branch) of the don state technical University. (p.336). Novocherkassk: Lik.

8. Golovko, V. A., et al. (2019). About the possibilities of normative documents developed in the framework of quality management (QMS) for the digital production of defect-free importsubstituting products: monograph / under the General editorship of Dr. of technical Sciences, Professor V. T. Prokhorov; the Institute of service sector and entrepreneurship (branch) don state technical University. (p.227). Novocherkassk: Lik.

9. Golovko, A. V., et al. (2019). Quality management system - the basis of technical regulation for production import-substituting products: monograph / edited by Dr. Techn. prof. V. T. Prokhorova; Institute of service and entrepreneurship (branch) of the don state technical University. (p.326). Novocherkassk: URGU (NPI). 


\begin{tabular}{llllll} 
& ISRA (India) $=\mathbf{3 . 1 1 7}$ & SIS (USA) & $=\mathbf{0 . 9 1 2}$ & ICV (Poland) & $=\mathbf{6 . 6 3 0}$ \\
Impact Factor: & ISI (Dubai, UAE) $=\mathbf{0 . 8 2 9}$ & PUHL (Russia) $=\mathbf{0 . 1 5 6}$ & PIF (India) & $=\mathbf{1 . 9 4 0}$ \\
& GIF (Australia) $=\mathbf{0 . 5 6 4}$ & ESJI (KZ) & $=\mathbf{8 . 7 1 6}$ & IBI (India) & $=\mathbf{4 . 2 6 0}$ \\
& JIF & $\mathbf{1 . 5 0 0}$ & SJIF (Morocco) $=\mathbf{5 . 6 6 7}$ & OAJI (USA) & $\mathbf{0 . 3 5 0}$ \\
\hline
\end{tabular}

10. (2017). GOST R 57189-2016/ISO/TS 9002:2016 quality management Systems. Guidelines for the application of ISO 9001: 2015 STANDARTINFORM, p.15.

11. Surovtseva, O. A., et al. (2018). Management of real quality of production, instead of advertizing through motivation of the leader of team of the enterprise of branch "is easy". monograph General ed. prof. V. T. Prokhorova (Eds.). Institute of service and entrepreneurship (branch) of the don state technical University. (p. 384). Novocherkassk: USU (NPI). 